\title{
Disinfection of simulated and real winery wastewater using sulphate radicals: Peroxymonosulphate/transition metal/UV-A LED oxidation
}

\author{
Jorge Rodríguez-Chueca ${ }^{\text {a, b, * }}$, Sónia I. Moreira a, Marco S. Lucas ${ }^{\mathrm{a}, \mathrm{c}}$, José R. Fernandes ${ }^{\mathrm{d}, \mathrm{e}}$, \\ Pedro B. Tavares ${ }^{a}$, Ana Sampaio ${ }^{f}$, José A. Peres ${ }^{a}$ \\ a Centro de Química de Vila Real, Departamento de Química, Universidade de Trás-os-Montes e Alto Douro (UTAD), 5000-801 Vila Real, Portugal \\ ${ }^{\mathrm{b}}$ Department of Chemical and Environmental Technology (ESCET), Universidad Rey Juan Carlos, C/ Tulipán s/n, 28933 Móstoles, Madrid, Spain \\ c Environmental Nanocatalysis \& Photoreaction Engineering, Chemical Engineering Department, Loughborough University, Loughborough, LE11 3TU, United \\ Kingdom \\ d Departamento de Física, UTAD - Universidade de Trás-os-Montes e Alto Douro, 5000-801 Vila Real, Portugal \\ e INESC-TEC, Rua do Campo Alegre, 687, 4169-007, Porto, Portugal \\ ${ }^{\mathrm{f}}$ CITAB, Departamento de Biologia e Ambiente, UTAD - Universidade de Trás-os-Montes e Alto Douro, 5000-801 Vila Real, Portugal
}

\section{A R T I C L E I N F O}

\section{Article history:}

Received 15 September 2016

Received in revised form

18 February 2017

Accepted 18 February 2017

Available online 20 February 2017

\section{Keywords:}

Sulphate radicals

Peroxymonosulphate

Bacterial inactivation

C. albicans inactivation

UV-A LED

\begin{abstract}
A B S T R A C T
The inactivation of four different microorganisms, Escherichia coli, Bacillus mycoides, Staphylococcus aureus and Candida albicans, inoculated in simulated (SWW) and real winery wastewaters (RWW), was assessed by the first time using free sulphate and hydroxyl radicals from photolytic (UV-A LED radiation; $370 \mathrm{~nm}$ ) and metal [Fe(II) or $\mathrm{Co}(\mathrm{II})]$ activation of peroxymonosulphate (PMS). The experimental conditions tested were $[\mathrm{PMS}]=0.1 \mathrm{mM}$ and $[\mathrm{Fe}(\mathrm{II})$ or $\mathrm{Co}(\mathrm{II})]=0.1 \mathrm{mM}$ and $\mathrm{pH} 5.0$ for the inactivation of microorganisms in SWW. However, due to the complexity of the water matrix, not unexpectedly, a fivefold concentration of reagents was required to inactivate the same organisms in RWW. In addition, compared to the bacteria, the fungus $C$. albicans presented a higher oxidative stress resistance to the treatments, and different experimental conditions were necessary to inactivate these cells.

After 90 min, the photolytic activation of PMS through UV-A LED radiation achieved complete inactivation of E. coli, followed by S. aureus $(\approx 4 \log$ ) and B. mycoides ( $\approx 3 \log$ ). Total inactivation of $C$. albicans was also achieved, but with higher dosages of PMS $(10 \mathrm{mM})$. The metal activation of PMS through the use of a transition metal [Fe(II) or $\mathrm{Co}(\mathrm{II})]$ accelerated the inactivation rate, particularly in the first minutes of exposure time. These treatments reached between 1 and $3 \log$ inactivation of microorganisms in the first minute of the experiment. In addition, the use of $\mathrm{Co}(\mathrm{II})$ as promoter in the activation of PMS, was more effective in the inactivation of S. aureus and C. albicans than activation with Fe(II).

Since linear mathematical models do not adjust satisfactorily to inactivation results in all cases, different mathematical models were tested to fit the experimental inactivation data. In general, the Hom model correctly fits the inactivation results of the four microorganisms in all applied treatments. However, other models such as Biphasic and Double Weibull fit acceptably as well.
\end{abstract}

๑) 2017 Elsevier Ltd. All rights reserved.

\section{Introduction}

The wine industry annually generates large volumes of winery wastewater $(\mathrm{WW})$. It is estimated that a winery produces between 1.3 and $1.5 \mathrm{~kg}$ of residues per liter of wine produced, $75 \%$ of which is

\footnotetext{
* Corresponding author. Centro de Química de Vila Real, Departamento de Química, Universidade de Trás-os-Montes e Alto Douro (UTAD), 5000-801 Vila Real, Portugal.

E-mail address: rodriguezchueca@gmail.com (J. Rodríguez-Chueca).
}

WW (Lucas et al., 2010). The effluents originate from various unit operations, and are characterized by a high organic load (Malandra et al., 2003), acidic pH and a high microbiological load (Jourjon et al., 2005).

In Portugal there is an increasing demand for water and a shortage of available water sources, thus one option for increasing existing resources is the treatment and reuse of wastewater. Frequently, WW are normally mixed with municipal effluents before their discharge into wastewater treatment plants (WWTPs).

In recent years, different countries and international organizations have issued laws or guidelines in order to regulate the reuse of 
treated wastewater (NP 4434:2005; WHO, 2006; USEPA, 2012). These laws, or guidelines, take into account the type of water reuse, including urban, agricultural, industrial, recreational, and environmental, and establish the maximum concentrations of contaminants permitted. One of the most strictly regulated parameters is pathogen content.

In the control of water microbiology, Escherichia coli is commonly used as a primary indicator of contamination due to its prevalence in the intestinal tract of warm-blooded animals (Leclerc et al., 2001). This Gram-negative is usually responsible for slight gastrointestinal diseases, but, depending on the strain virulence, it can also cause severe illness or death (Nataro and Kaper, 1998). Bacillus is a genus of rod-shaped Gram-positive bacteria, strictly aerobe or facultative anaerobe. It lives in the soil, seawater and rivers and frequently contaminates food. Under stressful conditions, it forms endospores, a form resistant to physical and chemical factors such as extreme temperatures, radiation and chemicals. Bacillus mycoides is a ubiquitous endospore former bacterium commonly found in soil, water, and air and on decomposing plants. As far as is known, this microorganism is not pathogenic and does not produce toxins, but is closely related to other pathogenic species such as B. cereus and B. anthracis (Drobniewski, 1993; Bottone, 2010), and can be used as a model of a Gram-positive and endospore-forming bacteria. Staphylococcus aureus is also a Grampositive bacteria, but one which lacks the ability to form endospores. It is often found in the skin, nose and other mucous membranes of warm-blooded animals and in a variety of food products. This species is potentially pathogenic and can cause food poisoning. In addition, it has become very important in both environmental and clinical microbiology, since many of its strains are resistant to methicillin (Methicillin-Resistant Staphylococcus aureus - MRSA) and are found frequently in hospital and sewage treatment plants (Börjesson et al., 2010; Goldstein et al., 2012; Thompson et al., 2012).

Along with other pathogenic fungi, Candida albicans has been isolated in activated sludge municipal WWTP (Awad and Kraume, 2011). It has a eukaryotic structure and is a fungus commonly found in human oral-anal and vaginal mucosa. In certain circumstances, this species causes opportunistic infections in immunocompromised patients (Calderone, 2002) which are seldom responsible for morbidity or mortality (Douglas, 1988).

In recent years, Advanced Oxidation Processes (AOPs) have gained importance in the treatment of agri-food wastewater (Santos et al., 2014; Cristóvão et al., 2015; Rodrigues et al., 2017). Recently, sulphate radical-based AOPs (SR-AOPs) in place of hydroxyl radical AOPs (HR-AOPs) have gradually attracted attention as in situ chemical oxidation technologies. SR-AOPs are performed by injecting chemical oxidants as persulfate salts, such as $\mathrm{Na}_{2} \mathrm{~S}_{2} \mathrm{O}_{8}$, $\mathrm{K}_{2} \mathrm{~S}_{2} \mathrm{O}_{8}$ and $\mathrm{KHSO}_{5}$ (Wei et al., 2015). Peroxymonosulphate ( $\mathrm{HSO}_{5}^{-}$; $\mathrm{PMS}$ ), is the active ingredient of potassium hydrogen monopersulphate $\left(2 \mathrm{KHSO}_{5} \cdot \mathrm{KHSO}_{4} \cdot \mathrm{K}_{2} \mathrm{SO}_{4}\right)$. The use of PMS as disinfectant agent has some advantages compared to hydrogen peroxide $\left(\mathrm{H}_{2} \mathrm{O}_{2}\right)$. Firstly, the oxidation potential of $\mathrm{HSO}_{5}^{-}\left(E_{\mathrm{HSO}_{5}^{-}}^{\circ} \mathrm{HSO}_{4}^{-}=1.82 \mathrm{~V}\right)$ is

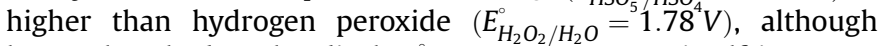
lower than hydroxyl radical $\left(E_{. \mathrm{OH}}^{\circ}=2.80 \mathrm{~V}\right)$. PMS itself is not an efficient disinfectant, but, due to the generated radicals, highly energetic and effective oxidizing agents, its action increases significantly when it is activated by a metal (Equation (1)), heat or light (Equation (2)), (Anipsitakis and Dionysiou, 2004a; Wang and Chu, 2012).

$\mathrm{HSO}_{5}{ }^{-}+\mathrm{M}^{n+} \rightarrow \mathrm{SO}_{4}{ }^{-}+\mathrm{M}^{(n+1)+}+\mathrm{OH}^{-}$

where $\mathrm{M}$ is a transition metal
$\mathrm{HSO}_{5} \stackrel{h \nu / \Delta}{\longrightarrow} \mathrm{SO}_{4} \cdot+\cdot \mathrm{OH}$

Different authors have reported the metal activation of PMS using different transition metals (Wang and Chu, 2012; Anipsitakis and Dionysiou, 2003; Anipsitakis et al., 2008), but some controversy remains over which is the best transition metal to activate PMS. For instance, the coupling of PMS/Fe(II) is one of the most commonly used, but it has some disadvantages similar to the Fenton process, such as the slow regeneration of $\mathrm{Fe}(\mathrm{II})$ and the production of ferric hydroxide sludge (Wang and Chu, 2012). In contrast, coupling PMS/Co(II) presents some advantages in comparison with Fenton treatments, the most relevant of which being the capability of using PMS/Co(II) without the need for $\mathrm{pH}$ adjustment (Bandala et al., 2007; Yu et al., 2006), but its main disadvantage is the toxicity of $\mathrm{Co}(\mathrm{II})$ for the environment.

The main objective of this research is to evaluate the performance of SR-AOPs (PMS/UV-A LED and PMS/M ${ }^{\mathrm{n}+} / \mathrm{UV}-\mathrm{A}$ LED using $\mathrm{Fe}(\mathrm{II})$ and $\mathrm{Co}(\mathrm{II})$ as PMS activator) in the inactivation of four different microorganisms present in winery wastewater samples (simulated and real): a) three different bacteria [E. coli (Gramnegative), $B$. mycoides (endospore-forming Gram-positive bacteria) and $S$. aureus (non-endospore-forming Gram-positive bacteria)] and b) one fungus (C. albicans).

Taking into account the different structure and composition of these microorganisms, their resistance to the treatments is studied and compared. Finally, the possibility of WW reuse in different unit operations in the winery (i.e. vineyard irrigation or cleaning of equipment) is assessed, from the perspective of the potential of this technology as an additional tertiary treatment option in a WWTP.

\section{Material and methods}

\subsection{Samples}

In this study, simulated winery wastewater (SWW), with a $\mathrm{pH}$

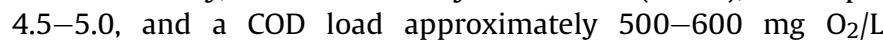
was used. SWW were simulated from Douro region red wine diluted samples. In addition, the treatments were tested on real winery wastewater (RWW) from a winery in the northern region of Portugal. Table 1 summarizes the characteristics of the samples.

\subsection{Microorganisms and culture media}

Different culture media were used to carry out microbial analyses. E. coli quantification was performed over the selective culture media Chromocult agar (Merck), whereas B. mycoides and S. aureus determination was carried out over Luria-Bertani (LB) agar. LB agar

Table 1

Physico-chemical characterization of simulated (SWW) and real (RWW) winery effluent (mean \pm standard deviation; $\mathrm{n}=25$ ).

\begin{tabular}{lll}
\hline Parameter & Sample & \\
\cline { 2 - 3 } & SWW & RWW \\
\hline pH & $4.5 \pm 0.1$ & $4.3 \pm 0.4$ \\
Redox potential $(\mathrm{mV})$ & $122 \pm 11$ & $156 \pm 23$ \\
Conductivity $(\mu \mathrm{S} / \mathrm{cm})$ & $38 \pm 2$ & $3200 \pm 120$ \\
Turbidity $(\mathrm{NTU})$ & $3 \pm 0.5$ & $217 \pm 40$ \\
Total Suspended solids $(\mathrm{mg} / \mathrm{L})$ & $1 \pm 0.2$ & $1030 \pm 150$ \\
COD $\left(\mathrm{mg} \mathrm{O}_{2} / \mathrm{L}\right)$ & $550 \pm 50$ & $5000 \pm 1000$ \\
Total polyphenols $($ Eq. mg gallic acid/L) & $33 \pm 4$ & $51 \pm 7$ \\
\hline
\end{tabular}


was prepared by mixing Tryptone $\left(10 \mathrm{~g} / \mathrm{L}\right.$; Difco $\left.{ }^{\circledR}\right), \mathrm{NaCl}(10 \mathrm{~g} / \mathrm{L}$; Merck), Yeast extract (5 g/L; Gibco Europe) and Agar-agar (1.5\%; Merck). Finally, C. albicans was quantified using Yeast Malt Extract $\operatorname{Agar}\left(\mathrm{YM}\right.$, Difco $\left.^{\circledR}\right)$.

The microorganisms used had different origins: E. coli and B. mycoides were wild strains isolated from well water and soil; and strains from a collection, such as Candida albicans ATCC 90028 and Staphylococcus aureus NCTC 10788/ATCC 6538, were also used. All of the microorganisms were used to prepare the microbial suspensions spiked in the SWW or RWW samples. Fresh liquid cultures were prepared in Luria-Bertarni broth (bacteria) or Yeast-Malt broth (yeast) and incubated at $37{ }^{\circ} \mathrm{C}$ in a rotary shaker (150 r.p.m.) for 20 h. These microbial suspensions were added to water samples ( $1 \mathrm{~mL}$ per $500 \mathrm{~mL}$ ) to obtain a concentration of microorganisms ranging from $10^{5}-10^{6}$ colony forming units (CFU)/ $100 \mathrm{~mL}$.

\subsection{Chemicals}

Oxidation treatments were carried out with different concentrations of Peroxymonosulphate $\left(\right.$ Merck $\left.^{\circledR}\right)$ coupled with transition metal $\left(\mathrm{CoSO}_{4} \cdot 7 \mathrm{H}_{2} \mathrm{O} ; \mathrm{FeSO}_{4} \cdot 7 \mathrm{H}_{2} \mathrm{O}\right.$, Panreac). In addition, sulphuric acid $\left(\mathrm{H}_{2} \mathrm{SO}_{4} \mathrm{Scharlau}\right)$ and sodium hydroxide ( $\mathrm{NaOH}$ Panreac) were used to adjust $\mathrm{pH}$ 5. All the reagents used were analytical grade. Deionized water was used throughout the study. In addition, UV-A LED radiation was used in combination with reagents in order to increase the concentration of sulphate radical anions.

\subsection{Physicochemical analyses}

Different physicochemical parameters were analyzed for wastewater characterization (Table 1 ). In addition, values of COD were analyzed at the end of the microorganism inactivation treatments.

COD was measured according to Method 410.4 of the U.S. Environmental Protection Agency (USEPA, 1993), using a HACH DR/ 2400 portable spectrophotometer. Turbidity was measured using a HACH 2100 IS Turbidimeter, while TSS were measured by spectrophotometry according to Standard Method 2540D using a $\mathrm{HACH}$ DR/2400 portable spectrophotometer (Eaton et al., 2005). Finally, TP concentration, (equivalents mg gallic acid/L), was determined by spectrophotometry using the Folin-Ciocalteu reagent (Merck) (Singleton and Rossi, 1965). UV-vis measurements were carried out using a Jasco V-530 UV/VIS spectrophotometer.

\subsection{Microorganisms analyses}

The analyses of the microorganisms E. coli, B. mycoides, S. aureus and $C$. albicans were performed by the spread plate method (Standard Method 9215C, (Eaton et al., 2005)) after a serial 10-fold dilution in sterilized saline solution $(\mathrm{NaCl} 0.9 \%)$. Aliquots of diluted samples were plated on Chromocult agar (Merck) for E. coli; LB agar for B. mycoides and S. aureus; and YMA (Yeast Malt Agar) for C. albicans. In all cases, colonies were counted after $24 \mathrm{~h}$ of incubation at $37{ }^{\circ} \mathrm{C}$. The detection limit (DL) of this experimental method was found to be $1 \mathrm{CFU} / \mu \mathrm{L}$.

The enumeration of colonies was expressed as CFU (colony forming units) per $100 \mathrm{~mL}$ of sample for each contact time. These concentrations were $\log 10$ transformed and the microbial rate removal, $\mathrm{D}=\log \left(\mathrm{N}_{\mathrm{t}} / \mathrm{N}_{0}\right)$, was calculated from the initial $\mathrm{CFU}\left(\mathrm{N}_{0}\right)$ and the final CFU at $\mathrm{t}$ time $\left(\mathrm{N}_{\mathrm{t}}\right)$.

\subsection{Experimental procedure}

Batch experiments were performed on $500 \mathrm{~mL}$ of winery wastewater at room temperature $\left(21-23^{\circ} \mathrm{C}\right)$. The $\mathrm{pH}$ of the winery wastewater was initially adjusted to $\mathrm{pH} 5$ using $\mathrm{NaOH}$. The assay began when the dosage of PMS $(0.1-10 \mathrm{mM})$ and the metal sulphate promoter $(0.1-5 \mathrm{mM})$ were added to the effluent simultaneously. In the photo-assisted experiments, the assay began when the UV radiation system was switched on, which also corresponded with the addition of PMS and the metal promoter. During the course of the reaction, samples were withdrawn at periodic intervals and analyzed. Finally, all the experiments were carried out in duplicate and the observed standard deviation was always less than $5 \%$ of the reported value.

\subsection{Regrowth analysis}

Microbial regrowth was estimated after the storage of the WW samples at room temperature for 24 and $48 \mathrm{~h}$, after the last sampling time t. The WW samples were kept in glass vials in the dark and the population was measured to assess the post-oxidation recovery, after their removal from the experimental set-up.

\subsection{Observation of endospores of B. mycoides}

The endospore staining of $B$. mycoides was carried out according to Schaeffer and Fulton (1933). Dried bacterial smears on glass slides were heat-fixed and stained with malachite green under heat, on a beaker of boiling water (5-6 min). After cooling the slide, the excess of malachite green was removed, the slide was washed with water and again stained with safranin for $30 \mathrm{~s}$. Using a Nikon Eclipse E600 light microscopy, and with $1000 \times$ magnification oil immersion lens, it was possible to observe that vegetative cells and endospores were dyed red or blue-green.

\section{9. $U V-A$ LED radiation ( $370 \mathrm{~nm}$ )}

The photo-assisted treatments were carried out in batch mode in a lab-scale prototype reactor and illuminated with a UV-A LED photo-system. The applied UV radiation in the photosystem was generated by a matrix of 96 Indium Gallium Nitride (InGaN) LEDs lamps (Roithner RLS-UV370E), which illuminated an area of $11 \times 7 \mathrm{~cm}^{2}$. These LEDs have a light peak emission at $370 \mathrm{~nm}$, and the nominal consumption of each LED lamp was $80 \mathrm{~mW}$ at an applied current of $20 \mathrm{~mA}$. The maximum average optical power was, approximately, $100 \mathrm{~mW}$. The array optical emission is controlled by using a pulse width modulation (PWM) circuit to modulate the electric current supplied to each LED of the array. This supply current is a square waveform that has two states: $0 \mathrm{~mA}$ (LED emission OFF state) and $30 \mathrm{~mA}$ (LED emission ON state) and frequency of $350 \mathrm{~Hz}$. The PWM module allows the configuration of the ON state time duration in each cycle between 0 and $100 \%$ of the cycle period and, consequently, the average optical power emitted can be set as a value between 0 and $100 \mathrm{~mW}$ depending on value of the root mean square (RMS) of the electric current intensity waveform supplied to the LED array by the PWM module. The system irradiance was measured using a UV enhanced Siphotodetector (ThorLabs PDA155) in a configuration that replicated the one used in the photoreactor. In this system, the output optical power was controlled using a pulse width modulation (PWM) circuit and the RMS current intensity was measured with a multimeter (UniVolt DT-64). The treatments were carried out with an RMS current intensity of $240 \mathrm{~mA}$, corresponding to a UV irradiance of $23 \mathrm{~W} / \mathrm{m}^{2}$ and a photon flux of $5.53 \times 10^{-7} \mathrm{E} / \mathrm{s}$. The application of this UV-A LED photo-system with successful results in the degradation of organic compounds has previously been reported (Rodríguez-Chueca et al., 2015, 2016a; 2017; Ferreira et al., 2016). 


\subsection{Kinetic modelling}

Frequently, disinfection processes are described by very simple kinetic models of a linear type, by the representation of microbial inactivation versus time. Nevertheless, linear kinetic models have many limitations and they are not able to describe certain deviations observed in microbial inactivation processes. Normally, the microbial inactivation representation is not linear and presents different curvilinear shapes: concave (shoulder) and convex (tail). Therefore, diverse mathematical inactivation models have been applied in this research in order to describe the inactivation rate of the studied microorganisms (Table S1. Supplementary Material). The adjustment of experimental values to the corresponding equations was carried out through two Microsoft ${ }^{\circledR}$ Excel add-in utilities: Solver and GInaFiT (Geeraerd and Van Impe Inactivation Fitting Tool) (Geeraerd et al., 2005). The assessment of the fit of the inactivation results was checked using two fitting parameters: the coefficient of determination $\left(\mathrm{R}^{2}\right)$ and the root-mean-square deviation (RMSD).

\section{Results}

Previous research into SWW optimal operational conditions, which indicates the viability of treatment application at circumneutral $\mathrm{pH}$, has been carried out by Rodríguez-Chueca et al. (2017), wherein pH 5 was selected since it matched typical effluent $\mathrm{pH}(\approx 4.5-5)$, thus avoiding extra costs for acidifying the effluent using additional technology, such as Fenton's reagent. Furthermore, microbial population does not survive $\mathrm{pH}$ values below 5 (Rodríguez-Chueca et al., 2012). Consequently, this pH value was selected as the minimum in order to study exclusively the effect of sulphate radicals on the inactivation of microorganisms in this research. In addition, different concentrations of PMS ranging from 0.1 to $2.5 \mathrm{mM}$ were tested. The use of PMS concentrations higher than $1 \mathrm{mM}$ resulted in the total inactivation of $E$. coli in the first minute of contact time. Since the aim was to monitor bacteria inactivation over time, a PMS concentration of $0.1 \mathrm{mM}$ was selected to monitor the treatment.

\subsection{Simulated winery wastewater}

\subsubsection{PMS/UV-A LED radiation}

Fig. 1 shows the inactivation results of different microorganisms after the combination of PMS with UV-A LED radiation $\left(23 \mathrm{~W} / \mathrm{m}^{2}\right.$; $240 \mathrm{~mA} ; 370 \mathrm{~nm}$ ). As can be observed in Fig. 1a, the application of PMS on SWW samples at a concentration of $0.1 \mathrm{mM}$ achieved a 4.70 $\log$ E. coli inactivation after $90 \mathrm{~min}$ of treatment. This treatment was accelerated through the activation of PMS with UV-A LED radiation. Subsequently, a disinfection of E. coli of 6.50-log units was reached after $90 \mathrm{~min}$ of treatment. Throughout the first $30 \mathrm{~min}$ of treatment, there was no difference between the two PMS treatments, presence or absence of UV-A LED radiation, but, thereafter, the inactivation rate increased when UV-A LEDs lamps irradiated the sample. In addition, as shown in Fig. 1, the samples irradiated with UV-A LED lamps, in the absence of PMS, did not register variations in E. coli population. This result clearly demonstrates that the inactivation of E. coli cells is a direct consequence of free sulphates and hydroxyl radicals generated through the irradiated activation of PMS (Eq. (2)).

The inactivation results were subjected to different kinetic models (Table S1, Supplementary Material). These mathematical models are useful to determine the inactivation rate of the treatments and the behaviour of cells under treatment. In Table 2, taking into account the kinetic parameters of models of linear first order (linear, Hom or linear with shoulder), it can be seen that the inactivation of $E$. coli under the combined PMS/UV-A LED treatment is faster than the treatment without radiation. The use of models based on a Weibull distribution (Weibull, Weibull with tail or Double Weibull) facilitates determination of the time required to achieve $1 \log$ of E. coli inactivation. According to the Double Weibull model (Table 2), inactivation under the treatment without UV-A LED radiation $\left(\delta_{1}=22.61 \mathrm{~min} ; \delta_{2}=58.31 \mathrm{~min}\right.$ ) was slightly faster than treatment with radiation $\left(\delta_{1}=24.96 \mathrm{~min} ; \delta_{2}=80.97 \mathrm{~min}\right)$.

In contrast, Fig. 1b shows that the inactivation results of B. mycoides under same conditions are completely different from those displayed by $E$. coli. The inactivation rate, during the first minutes of the treatment was higher than E. coli. After 5 min of contact time, the inactivation of $B$. mycoides reached 1.30 and 1.98 $\log$ with 0.1 and $0.5 \mathrm{mM}$ of PMS respectively, whilst in the case of E. coli, only $0.15 \mathrm{log}$ was achieved. This response can be modeled using the kinetic parameters shown in Table 2. For instance, the comparison of models such as Hom, Linear with shoulder and tail, Weibull and Double Weibull confirms that the inactivation rate of $B$. mycoides was higher than in $E$. coli, obtaining higher values of $k$ and lower values of $\delta$. However, despite having a higher inactivation rate, the maximum inactivation yield of $B$. mycoides did not achieve 3-log after 90 min of treatment, in contrast to E. coli, where total inactivation was reached for the same reaction time. It was also observed that the $B$. mycoides population stabilized after $15 \mathrm{~min}$ until the end of the assay. This behaviour seems to be due to the generation of Bacillus spores, the most resistant form of this kind of bacteria. Thus, the inactivation achieved applies only to vegetative cells. The de novo formation of endospores by $B$. mycoides was confirmed through the application of Schaeffer and Fulton stain at the beginning and after $30 \mathrm{~min}$ of the experiment.

Fig. 1c shows the inactivation results for $S$. aureus, a nonendospore forming Gram-positive bacteria, in contrast to the inactivation pattern of an endospore-forming Gram-positive bacteria (B. mycoides). The application of $0.1 \mathrm{mM}$ of PMS combined with UV-A LED radiation achieved $4.02 \mathrm{log}$ after $120 \mathrm{~min}$ (Fig. 1c). This inactivation rate was slightly higher than treatment in the dark (3.56 log). A comparison of the kinetic parameters of the three bacteria studied clearly shows that the highest inactivation rate was for E. coli, followed by S. aureus and B. mycoides. The inactivation results of $S$. aureus obtained using PMS/UV-A LED treatment (4.02 log) were higher than those obtained for B. mycoides (2.82 log) but lower than those obtained for E. coli $(6.50 \mathrm{log})$.

Regarding the fungi $C$. albicans, achieving the DL of analysis of C. albicans in 120 min necessitated the increase of the PMS concentration to $10 \mathrm{mM}$. The concentrations used to reach the inactivation of bacteria (0.1-0.5 mM of PMS) were not enough to cause damages in the cells of $C$. albicans. With the combination $10 \mathrm{mM}$ PMS/UV-A LED, a reduction of $4.67 \log$ (reached DL) after $120 \mathrm{~min}$ of treatment was achieved. After $30 \mathrm{~min}$ of contact time, 1-log inactivation of $C$. albicans had not been attained. However, from this point on, the population began to fall drastically until it reached DL at $120 \mathrm{~min}$. Although $C$. albicans, shows higher resistance compared to the three bacteria (Fig. 1d), the inactivation rate cannot be easily compared with those obtained for bacteria because of the difference in the initial dosage of PMS. However, the Weibull with tail, Double Weibull and Biphasic with shoulder mathematical models showed an excellent fit for the inactivation results $\left(R^{2}=0.99\right)$. The last two models describe the inactivation results from the hypothesis that microbial population is divided in two sub-groups with different resistance to the treatment. The Double Weibull model presented $\delta$ values of 35.98 and $115.54 \mathrm{~min}$ for the first and the second sub-group.

\subsection{2. $P M S / M^{n+} / U V-A$ LED radiation}

With the aim of increasing the inactivation rate of all the studied microorganisms, the metal activation of PMS using 

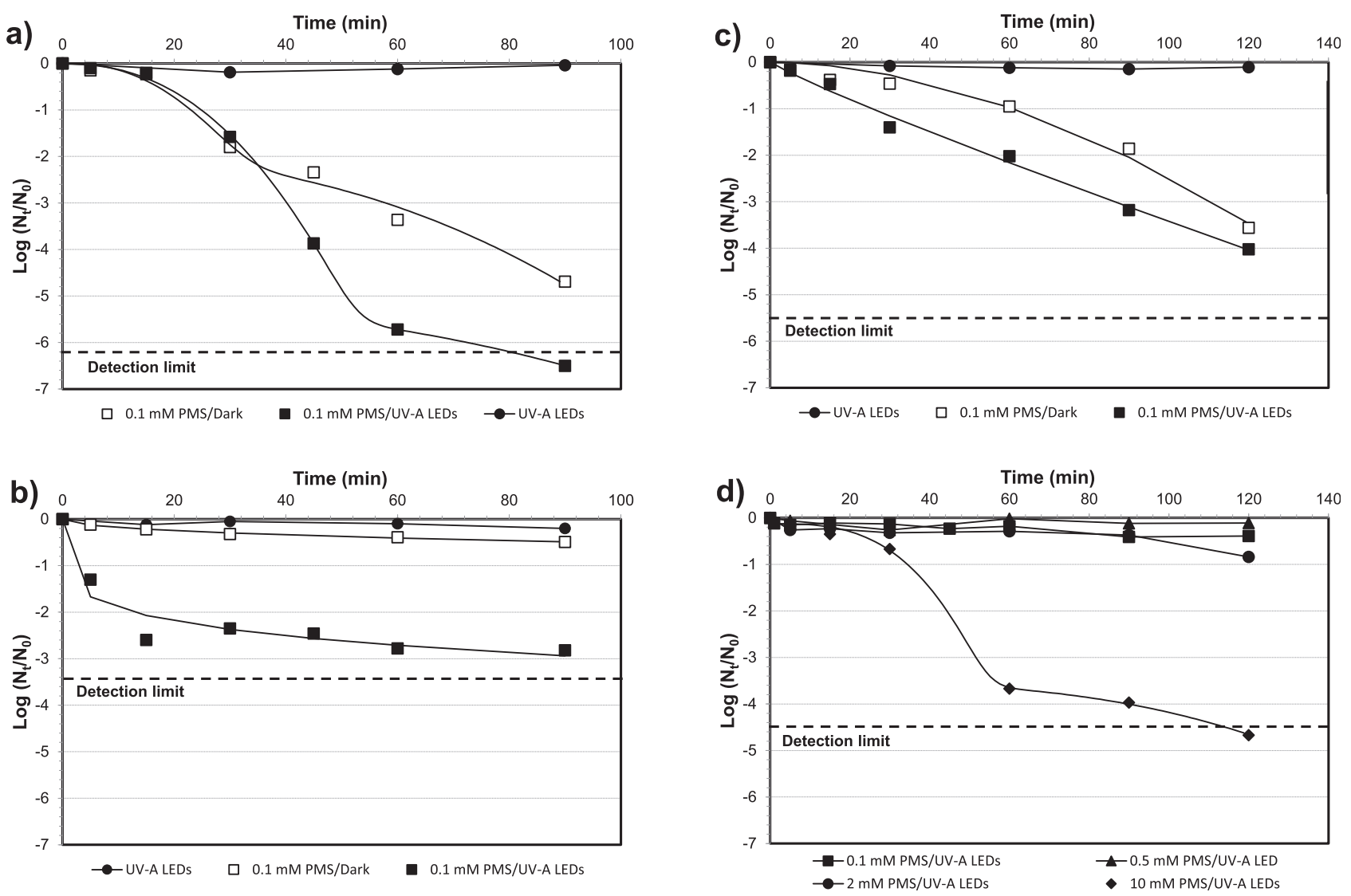

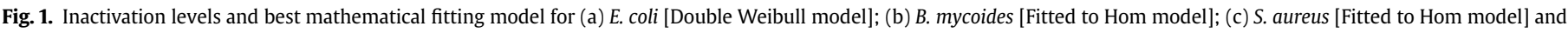
(d) C. albicans [Fitted to Double Weibull model] in SWW after the application of PMS/UV-A LED; PMS/dark, and UV-A LED treatments.

$\mathrm{Fe}(\mathrm{II})$ and $\mathrm{Co}(\mathrm{II})$ in combination with UV-A LED radiation was explored.

As shown in Eq. (1), PMS can be activated by transition metals. Fig. 2 shows the combination of PMS with a transition metal, [Fe(II) or $\mathrm{Co}(\mathrm{II})]$, in the inactivation treatment of the four microorganisms.
As seen in Fig. 2a, the activation of PMS using a transition metal noticeably accelerated the inactivation rate of $E$. coli, in the first minute of contact. At this point, the inactivation of $E$. coli was 3.2 and $4.2 \mathrm{log}$ with $\mathrm{Co}$ (II) and Fe (II), respectively. However, after this time and until the end of the experiment, the E. coli population

Table 2

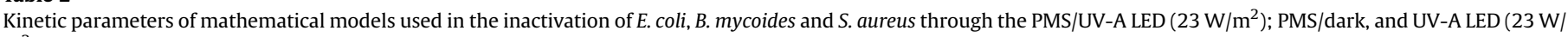
$\mathrm{m}^{2}$ ) treatments in SWW.

\begin{tabular}{|c|c|c|c|c|c|c|c|c|c|}
\hline \multirow[t]{2}{*}{ Kinetic model } & \multicolumn{3}{|l|}{ E. coli } & \multicolumn{3}{|l|}{ B. mycoides } & \multicolumn{3}{|l|}{ S. aureus } \\
\hline & $\begin{array}{l}k_{1}\left(\min ^{-1}\right) / \\
\delta_{1}(\min )\end{array}$ & $\begin{array}{l}k_{2}\left(\min ^{-1}\right) / \\
\delta_{2}(\min )\end{array}$ & $\mathrm{R}^{2} / \mathrm{RMSD}$ & $\begin{array}{l}k_{1}\left(\min ^{-1}\right) / \\
\delta_{1}(\min )\end{array}$ & $\begin{array}{l}k_{2}\left(\min ^{-1}\right) / \\
\delta_{2}(\min )\end{array}$ & $\mathrm{R}^{2} / \mathrm{RMSD}$ & $\begin{array}{l}k_{1}\left(\min ^{-1}\right) / \\
\delta_{1}(\min )\end{array}$ & $\begin{array}{l}k_{2}\left(\min ^{-1}\right) / \\
\delta_{2}(\min )\end{array}$ & $R_{2} /$ RMSD \\
\hline \multicolumn{10}{|c|}{$0.1 \mathrm{mM} P M S / D a r k$} \\
\hline $\mathrm{L}(k)$ & 0.13 & - & $0.98 / 0.28$ & 0.01 & - & $0.89 / 0.07$ & 0.06 & - & $0.92 / 0.39$ \\
\hline $\mathrm{H}(k)$ & 0.04 & - & $0.98 / 0.25$ & 0.06 & & $0.99 / 0.01$ & 0.0005 & - & $0.99 / 0.17$ \\
\hline $\mathrm{LS}(k)$ & 0.13 & - & $0.98 / 0.31$ & - & - & - & 0.10 & - & $0.98 / 0.24$ \\
\hline $\mathrm{LT}(k)$ & - & - & - & 0.05 & - & $0.97 / 0.04$ & - & - & - \\
\hline $\mathrm{W}(\delta)$ & 17.73 & - & $0.98 / 0.31$ & 437.34 & - & $0.99 / 0.02$ & 69.55 & - & $0.99 / 0.15$ \\
\hline $\mathrm{DW}(\delta)$ & 22.61 & 58.31 & $0.99 / 0.25$ & - & - & - & 7.71 & 76.57 & $0.99 / 0.03$ \\
\hline $\mathrm{B}(k)$ & 0.13 & 0.01 & $0.98 / 0.34$ & 0.16 & 0.01 & $0.99 / 0.02$ & - & - & - \\
\hline \multirow{2}{*}{\multicolumn{10}{|c|}{$0.1 \mathrm{mM} P M S+U V-A$ LED $\left(23 \mathrm{~W} / \mathrm{m}^{2}\right)$}} \\
\hline & & & & & & & & & \\
\hline $\mathrm{L}(k)$ & 0.19 & - & $0.94 / 0.73$ & - & - & - & 0.08 & - & $0.99 / 0.17$ \\
\hline $\mathrm{H}(k)$ & 0.06 & - & $0.94 / 0.65$ & 1.22 & - & $0.93 / 0.25$ & 0.05 & - & $0.99 / 0.12$ \\
\hline $\mathrm{LS}(k)$ & 0.20 & - & $0.95 / 0.79$ & - & - & - & - & - & - \\
\hline $\mathrm{LT}(k)$ & - & - & - & 0.61 & - & $0.97 / 0.20$ & - & - & - \\
\hline LST $(k)$ & 0.32 & - & $0.99 / 0.10$ & - & - & - & - & - & - \\
\hline $\mathrm{W}(\delta)$ & 11.34 & - & $0.94 / 0.82$ & 0.34 & - & $0.93 / 0.34$ & 24.41 & - & $0.99 / 0.16$ \\
\hline $\mathrm{WT}(\delta)$ & 21.60 & - & $0.99 / 0.25$ & - & - & & - & - & - \\
\hline $\mathrm{DW}(\delta)$ & 24.96 & 80.97 & $0.99 / 0.07$ & 4.38 & 139.33 & $0.99 / 0.16$ & - & - & - \\
\hline $\mathrm{B}(k)$ & - & - & - & 0.63 & 0.01 & $0.99 / 0.17$ & 0.14 & 0.07 & $0.99 / 0.18$ \\
\hline BS $(k)$ & - & - & - & 1.06 & 0.01 & $0.99 / 0.21$ & 0.39 & 0.07 & $0.99 / 0.18$ \\
\hline
\end{tabular}



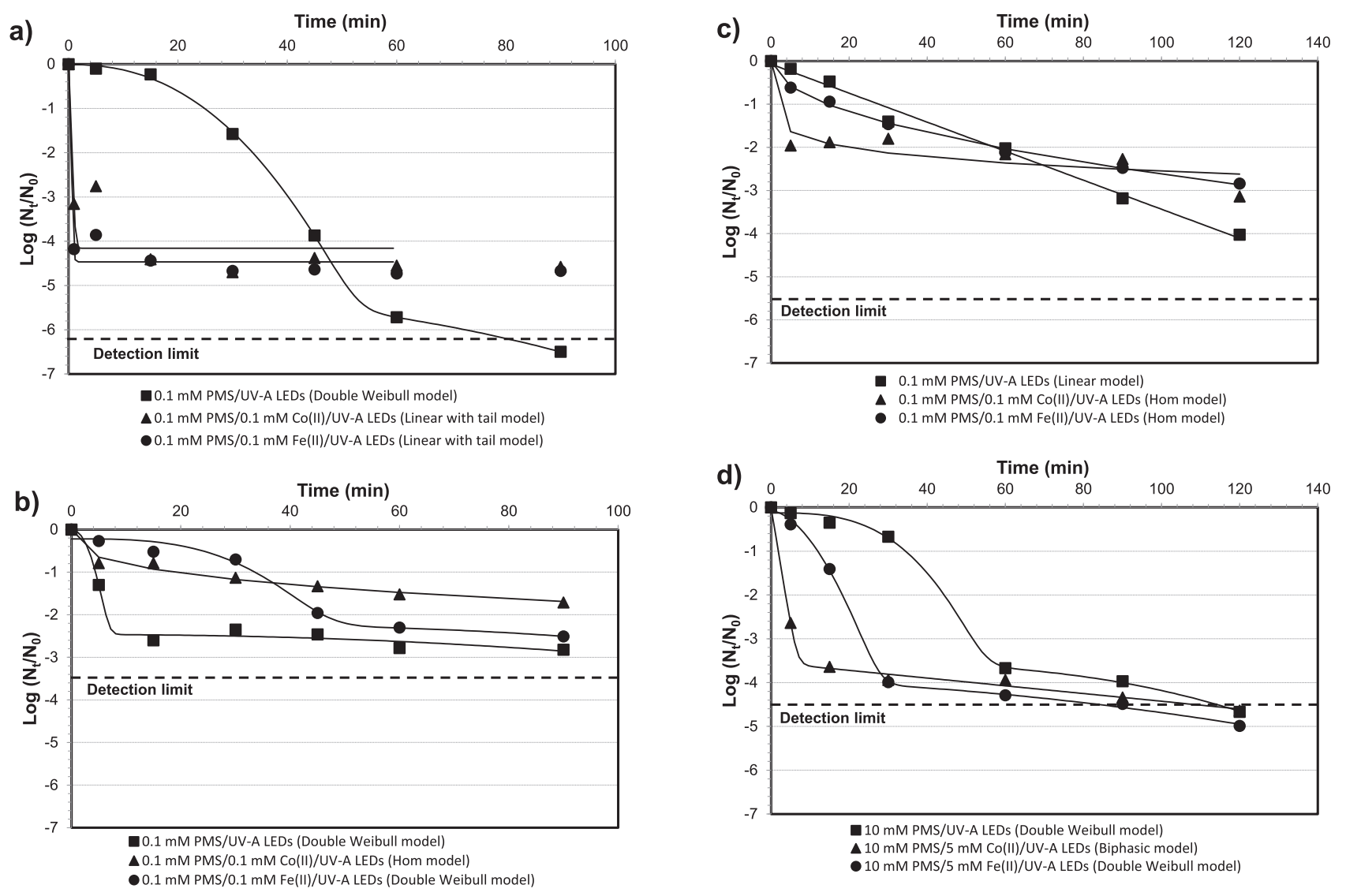

Fig. 2. Inactivation levels of (a) E. coli; (b) B. mycoides; (c) S. aureus and (d) C. albicans in SWW after the application of PMS/M ${ }^{\mathrm{n}+}$ [Fe(II) or Co(II)]/UV-A LED.

remained stable. This may have been due to the total consumption of PMS and metal activator, since, if any residual PMS remained, the E. coli population could have continued decreasing at a lower rate due to the photolysis of PMS in combination with UV-A radiation. Nevertheless, this continued decrease was not observed. The efficacy of PMS $/ \mathrm{M}^{\mathrm{n}+} / \mathrm{UV}-\mathrm{A}$ LED treatments was tested on the population of B. mycoides (Fig. 2b) and resulted in low inactivation rates. After the first five minutes, the inactivation values reached 0.27 and $0.79 \log$ with $\mathrm{Fe}(\mathrm{II})$ and $\mathrm{Co}(\mathrm{II})$ respectively, while treatment without a transition metal achieved $1.30 \mathrm{log}$. This effect on B. mycoides is probably the consequence of endospore production, triggered by the harsh and toxic environment caused by the metal concentration and sulphate radicals and the rapid generation of these radicals during the PMS $/ \mathrm{M}^{\mathrm{n}+} / \mathrm{UV}-\mathrm{A}$ LED treatment. After the fifth minute of contact, with $\mathrm{Fe}(\mathrm{II})$ or $\mathrm{Co}$ (II) the inactivation increased slowly, reaching 2.51 and $1.71 \log$ respectively after 90 min of reaction time. However, in the absence of a transition metal, the generation of sulphate radicals was slower (data not shown).

In the case of a non-endospore-producing Gram-positive bacteria, S. aureus, the pattern was totally different (Fig. 2c). The combination of PMS (0.1 mM) and $\mathrm{Co}(\mathrm{II})$ achieved an inactivation level for $S$. aureus of $2 \log$ in the first five minutes of the contact time. After this time, the inactivation rate remained stable until $90 \mathrm{~min}$, increasing afterwards and reaching a final yield of $3.14 \mathrm{log}$ at $120 \mathrm{~min}$. The treatment of $S$. aureus using a combination of PMS and $\mathrm{Fe}(\mathrm{II})$ resulted in a final inactivation yield similar to that in the case of $\mathrm{Co}$ (II) (2.84). Nevertheless, with an inactivation level 4.02 $\log$ after $120 \mathrm{~min}$, the inactivation rates for $S$. aureus were lower with, or without, a transition metal in the treatment.

Table 3 shows the inactivation kinetic parameters of the three bacteria after the application of PMS/M ${ }^{\mathrm{n}+} / \mathrm{UV}-\mathrm{A}$ LED treatments. It is worth mentioning that a low number of models achieved a good fit for inactivation values of $E$. coli. All of the bacteria treatments that combined PMS/Co(II) were slightly faster than the PMS/Fe(II) treatments. In addition, comparison with results shown in Table 2, shows that the metal activation of a PMS with a transition metal leads to significantly faster inactivation rates than treatments without a transition metal (PMS/UV-A LED), because of the higher generation of sulphate radicals.

In the case of the fungus, C. albicans, (the combination of PMS $(10 \mathrm{mM})$ with a metal transition concentration [5 $\mathrm{mM}$ of $\mathrm{Fe}(\mathrm{II})$ or $\mathrm{Co}(\mathrm{II})]$ achieved total inactivation. As shown in Fig. 2d), the combination PMS/Co(II)/UV-A LED reached $3.64 \mathrm{log}$ after $15 \mathrm{~min}$ of contact time, whilst the yield was $1.41 \log$ using $\mathrm{Fe}(\mathrm{II})$ and $0.35 \mathrm{log}$ in absence of any transition metal. After $30 \mathrm{~min}$, the inactivation rate stabilized until it reaches the DL (120 min of treatment). The kinetic study of the inactivation results made this clear, since Double Weibull and Biphasic models aptly fitted the inactivation results. Taking into account the rates obtained with the Double Weibull model, $\delta$ values of 12.54 and 122.25 min were obtained in treatments carried out with $\mathrm{Fe}(\mathrm{II})$, whilst 0.00375 and $0.0687 \mathrm{~min}$ were obtained with $\mathrm{Co}(\mathrm{II})$. Therefore, the analysis and the comparison of the kinetic rates clearly shows that the combination of PMS with a transition metal considerably increased the inactivation rate of $C$. albicans, especially using $\mathrm{Co}$ (II).

With the objective of increasing the inactivation rate and reaching total inactivation, a second addition of $\mathrm{PMS} / \mathrm{M}^{\mathrm{n}+}$ was proposed. The results obtained are shown in Fig. 3. This second addition was performed at $15 \mathrm{~min}$ after the beginning of the treatment using the same concentrations of PMS and transition metals. As shown in Fig. 3a, because of the second addition, an almost total inactivation of $E$. coli $(6.5 \mathrm{log})$ was attained some 
Table 3

Kinetic parameters of mathematical models used in the inactivation of E. coli, B. mycoides and S. aureus through the PMS/M ${ }^{\mathrm{n}+} / \mathrm{UV}-\mathrm{A}$ LED (23 W/m $\left.{ }^{2}\right)$ treatments in SWW.

\begin{tabular}{|c|c|c|c|c|c|c|c|c|c|}
\hline \multirow[t]{2}{*}{ Kinetic model } & \multicolumn{3}{|l|}{ E. coli } & \multicolumn{3}{|l|}{ B. mycoides } & \multicolumn{3}{|l|}{ S. aureus } \\
\hline & $\begin{array}{l}k_{1}\left(\min ^{-1}\right) / \\
\delta_{1}(\min )\end{array}$ & $\begin{array}{l}k_{2}\left(\min ^{-1}\right) / \\
\delta_{2}(\min )\end{array}$ & $\overline{\mathrm{R}^{2} / \mathrm{RMSD}}$ & $\begin{array}{l}k_{1}\left(\min ^{-1}\right) / \\
\delta_{1}(\min )\end{array}$ & $\begin{array}{l}k_{2}\left(\min ^{-1}\right) / \\
\delta_{2}(\min )\end{array}$ & $\overline{\mathrm{R}^{2} / \mathrm{RMSD}}$ & $\begin{array}{l}k_{1}\left(\min ^{-1}\right) / \\
\delta_{1}(\min )\end{array}$ & $\begin{array}{l}k_{2}\left(\min ^{-1}\right) / \\
\delta_{2}(\min )\end{array}$ & $\overline{\mathrm{R}^{2} / \mathrm{RMSD}}$ \\
\hline \multicolumn{10}{|c|}{$0.1 \mathrm{mM} P M S+0.1 \mathrm{mM} F e(I I)+U V-A$ LED $\left(23 \mathrm{~W} / \mathrm{m}^{2}\right)$} \\
\hline $\mathrm{L}(k)$ & - & - & - & 0.07 & - & $0.91 / 0.34$ & 0.05 & - & $0.92 / 0.33$ \\
\hline $\mathrm{H}(k)$ & - & - & - & 0.07 & - & $0.92 / 0.27$ & 0.27 & - & $0.99 / 0.05$ \\
\hline $\mathrm{LT}(k)$ & 10.35 & - & $0.97 / 0.36$ & - & - & - & 0.08 & - & $0.97 / 0.22$ \\
\hline $\operatorname{LST}(k)$ & - & - & - & 0.22 & - & $0.98 / 0.22$ & - & - & - \\
\hline $\mathrm{W}(\delta)$ & - & - & - & 23.68 & - & $0.92 / 0.36$ & 14.07 & - & $0.99 / 0.06$ \\
\hline $\mathrm{WT}(\delta)$ & - & - & - & 36.09 & - & $0.98 / 0.21$ & - & - & - \\
\hline $\mathrm{DW}(\delta)$ & - & - & - & 36.04 & 137.53 & $0.98 / 0.19$ & - & - & - \\
\hline $\mathrm{B}(k)$ & - & - & - & 0.09 & 0.00 & $0.95 / 0.31$ & 0.15 & 0.03 & $0.99 / 0.14$ \\
\hline $\mathrm{BS}(k)$ & - & - & - & 0.25 & 0.01 & $0.98 / 0.25$ & 0.15 & 0.03 & $0.99 / 0.17$ \\
\hline \multicolumn{10}{|c|}{$0.1 \mathrm{mM} P M S+0.1 \mathrm{mM} C \mathrm{Co}(\mathrm{II})+U V-A$ LED $\left(23 \mathrm{~W} / \mathrm{m}^{2}\right)$} \\
\hline $\mathrm{H}(k)$ & - & - & - & 0.38 & - & $0.98 / 0.08$ & 1.28 & - & $0.89 / 0.29$ \\
\hline $\mathrm{LT}(k)$ & 7.38 & - & $0.85 / 0.79$ & 0.07 & - & $0.89 / 0.23$ & - & - & - \\
\hline $\mathrm{W}(\delta)$ & - & - & - & 21.38 & - & $0.98 / 0.11$ & - & - & - \\
\hline $\mathrm{DW}(\delta)$ & - & - & - & - & - & - & - & - & - \\
\hline $\mathrm{B}(k)$ & 0.86 & 0.002 & $0.76 / 0.99$ & - & - & - & - & - & - \\
\hline $\mathrm{BS}(k)$ & - & - & - & - & - & - & - & - & - \\
\hline
\end{tabular}

minutes after the second addition, both with $\mathrm{Fe}(\mathrm{II})$ and $\mathrm{Co}(\mathrm{II})$. However, small differences were observed with the use of the two transition metals. In the case of $B$. mycoides (Fig. 3b), the second addition of the reagents had practically no effect on the inactivation of the B. mycoides population. Only when PMS was combined with $\mathrm{Fe}(\mathrm{II})$ was a slight tendency to increase the inactivation yield observed. Nevertheless, the second addition did not result in higher inactivation values. In contrast, in the case of $S$. aureus, a significant decrease in population was observed after the second addition of
PMS/Co(II), reaching $5.17 \log$ at $30 \mathrm{~min}$ and the detection limit of the analysis (6.17 log) after 120 min of treatment. Although, when $\mathrm{PMS} / \mathrm{Fe}(\mathrm{II})$ was added at the fifteenth minute for the second time, no enhancement in the inactivation of $S$. aureus population was observed.

In the case of $C$. albicans (Fig. $3 d)$ the $\mathrm{DL}(\approx 5 \log$ ) was reached both with $\mathrm{Fe}(\mathrm{II})$ and $\mathrm{Co}(\mathrm{II})$ after the second addition of reagents (30 min of contact time), and the highest inactivation rate was reached using a combination of PMS with $\mathrm{Co}(\mathrm{II})$.
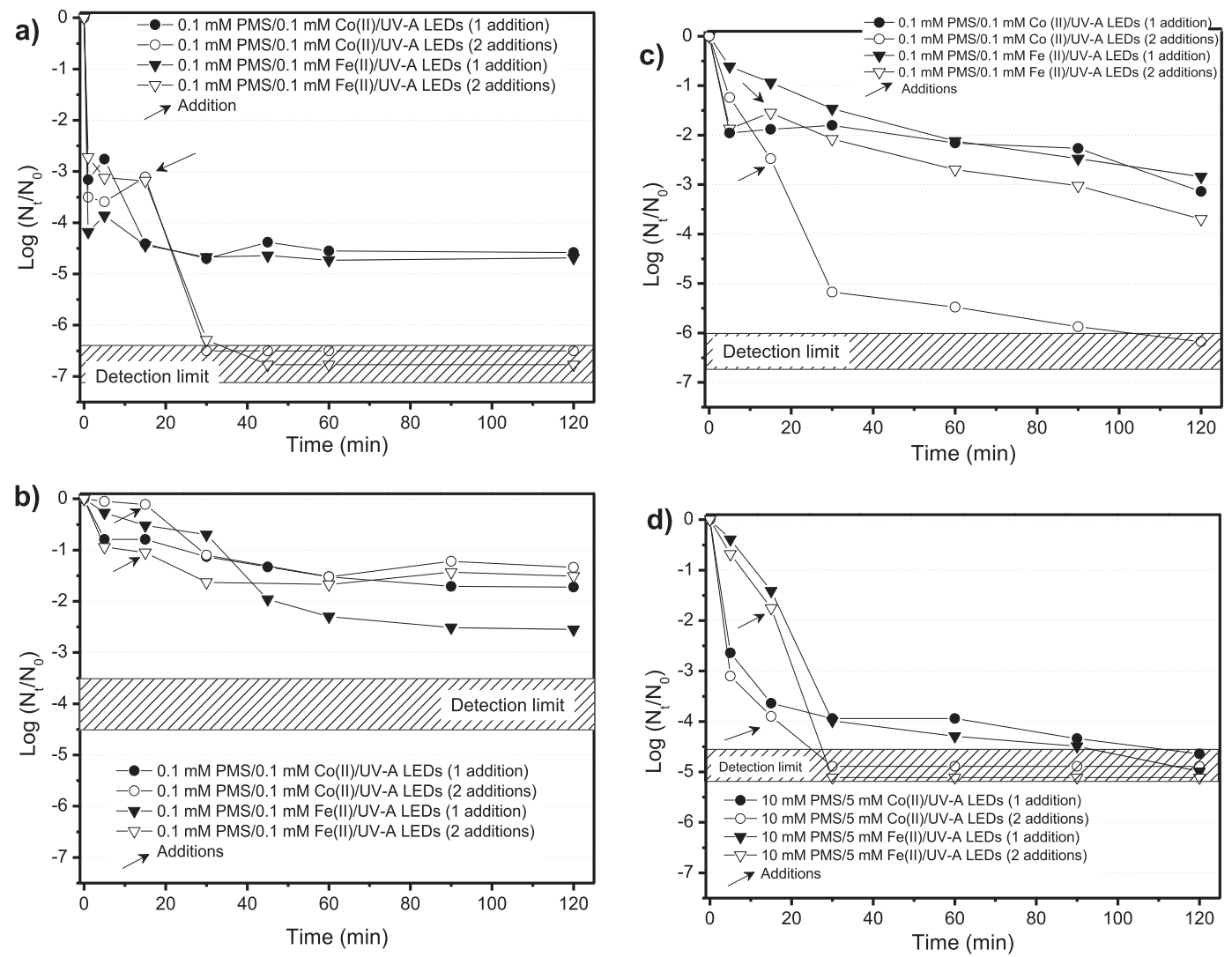


reagents. 
Table 4

Values of COD removal in SWW and RWW. ND - not determined.

\begin{tabular}{|c|c|c|c|c|c|c|}
\hline \multirow[t]{2}{*}{ Treatments } & \multicolumn{3}{|l|}{ SWW } & \multicolumn{3}{|l|}{ RWW } \\
\hline & $\mathrm{COD}_{\mathrm{i}}\left(\mathrm{mgO}_{2} / \mathrm{L}\right)$ & $\mathrm{COD}_{\mathrm{f}}\left(\mathrm{mgO}_{2} / \mathrm{L}\right)$ & COD removal (\%) & $\mathrm{COD}_{\mathrm{i}}\left(\mathrm{mgO}_{2} / \mathrm{L}\right)$ & $\mathrm{COD}_{\mathrm{f}}\left(\mathrm{mgO}_{2} / \mathrm{L}\right)$ & COD removal (\%) \\
\hline UV-A LED $\left(23 \mathrm{~W} / \mathrm{m}^{2}\right)$ & 540 & 537 & 1 & 4250 & 4240 & 0 \\
\hline $0.1 \mathrm{mM}$ PMS/UV-A LED & 616 & 356 & 42 & 3695 & 3645 & 1 \\
\hline $0.5 \mathrm{mM}$ PMS/UV-A LED & 500 & 246 & 51 & 4975 & 4800 & 4 \\
\hline 10 mM PMS/UV-A LED & 486 & 332 & 32 & 3276 & 3240 & 1 \\
\hline \multicolumn{7}{|c|}{ PMS $/ \mathbf{M}^{\mathbf{n}+} / \mathrm{UV}-\mathbf{A}$ LED -1 addition } \\
\hline 0.1/0.1 mM PMS/Fe (II) & 516 & 275 & 47 & 2473 & 2889 & 0 \\
\hline 0.1/0.1 mM PMS/Co (II) & 493 & 264 & 46 & 3401 & 3291 & 3 \\
\hline 0.5/0.5 mM PMS/Fe (II) & 434 & 297 & 32 & 2318 & 2178 & 6 \\
\hline 0.5/0.5 mM PMS/Co (II) & N.D. & N.D. & N.D. & 2041 & 1998 & 2 \\
\hline 10/5 mM PMS/Fe (II) & 540 & 325 & 40 & 2905 & 2786 & 4 \\
\hline 10/5 mM PMS/Co (II) & 428 & 163 & 62 & 2992 & 2848 & 5 \\
\hline \multicolumn{7}{|c|}{ PMS/M $/ \mathbf{M}^{\mathrm{n}+} / \mathrm{UV}-\mathrm{A}$ LED -2 additions } \\
\hline $0.1 / 0.1 \mathrm{mM}$ PMS/Fe (II) & 568 & 316 & 44 & 3400 & 3280 & 4 \\
\hline 0.1/0.1 mM PMS/Co (II) & 519 & 325 & 37 & 2585 & 2352 & 9 \\
\hline 0.5/0.5 mM PMS/Fe (II) & N.D. & N.D. & N.D. & 2358 & 2318 & 2 \\
\hline 0.5/0.5 mM PMS/Co (II) & N.D. & N.D. & N.D. & 1984 & 1921 & 3 \\
\hline 10/5 mM PMS/Fe (II) & 510 & 212 & 58 & 1788 & 1609 & 10 \\
\hline 10/5 mM PMS/Co (II) & 526 & 78 & 85 & 2643 & 2046 & 23 \\
\hline
\end{tabular}

Parallel with the microbial inactivation assays, COD removal was assessed at the end of the PMS/UV-A LED and PMS/M $\mathrm{M}^{\mathrm{n}+} / \mathrm{UV}-\mathrm{A}$ LED treatments (Table 4). PMS/UV-A LED treatments reached significant values of COD removal after 120 min of treatment. Using $0.1 \mathrm{mM}$ of PMS, $42 \%$ of the organic matter was removed. This result was augmented up to $51 \%$ by a five-fold increase in the dosage of PMS. However, the opposite effect was observed using a larger dosage of PMS. For instance, with $10 \mathrm{mM}$ of PMS only $32 \%$ of organic matter was removed. These results provide confirmatory evidence that an excess of PMS produces the emergence of a scavenger effect (Sun et al., 2009). In contrast, the metal activation of PMS using a transition metal slightly increased the COD removal yield to 46 and $47 \%$ using $0.1 \mathrm{mM}$ of PMS mixed with Co (II) and Fe(II) respectively. The increase of reagent dosage $\left(10 / 5 \mathrm{mM} P M S / \mathrm{M}^{\mathrm{n}+}\right)$ resulted in an increase in the yield, reaching $62 \%$ after the application of $\mathrm{Co}(\mathrm{II})$. However the yield decreased when Fe(II) was applied (40\%). Finally, the second addition of reagents at the fifteenth minute increased the yield when the highest set of reagent's doses was applied, reaching final values of 58 and $85 \%$ using $\mathrm{Fe}(\mathrm{II})$ and $\mathrm{Co}(\mathrm{II})$ respectively. The latter value falls within current guidelines of European wastewater treatment legislation (European Directive 91/271/EEC).

A closer look at the data indicates that PMS $/ \mathrm{M}^{\mathrm{n}+} / \mathrm{UV}-\mathrm{A}$ LED treatments using low dosages of reagents $\left(0.1 \mathrm{mM}\right.$ of PMS and $\mathrm{M}^{\mathrm{n}+}$ ) are enough to achieve a large inactivation of microbial population and a significant reduction in COD. However, in the cases of resistant organisms such as B. mycoides and C. albicans, higher dosages of reagents are required to achieve their total inactivation. In this research, the survival of E. coli, B. mycoides and S. aureus using the concentrations of PMS and $\mathrm{M}^{\mathrm{n}+}$ applied for the inactivation of C. albicans was also analyzed. In all cases, the total inactivation of microbial population after the fifth minute of contact time was observed (data not shown). Consequently, these operational conditions allow obtention of the total inactivation of bacteria and fungi in conformity with European legislation on wastewater treatment (European Directive 91/271/EEC) and Portuguese legislation regarding wastewater reuse (NP 4434:2005) in terms of COD values. Further research in this area may include PMS $/ \mathrm{M}^{\mathrm{n}+} / \mathrm{UV}-\mathrm{A}$ LED treatments as a tertiary treatment in reuse WWTP.

\subsection{Real winery wastewater}

After testing the effect on microbial inactivation of several treatments in a SWW, we choose to perform the same treatments in a more complex water matrix, RWW, in order to understand the impact of the environment in the disinfection process. The application of PMS/UV-A LED and PMS/M $\mathrm{M}^{\mathrm{n}+} / \mathrm{UV}-\mathrm{A}$ LED treatments were carried out on RWW inoculated with E. coli, B. mycoides and $S$. aureus. According to Fig. $4 \mathrm{a}$ and in comparison with previous
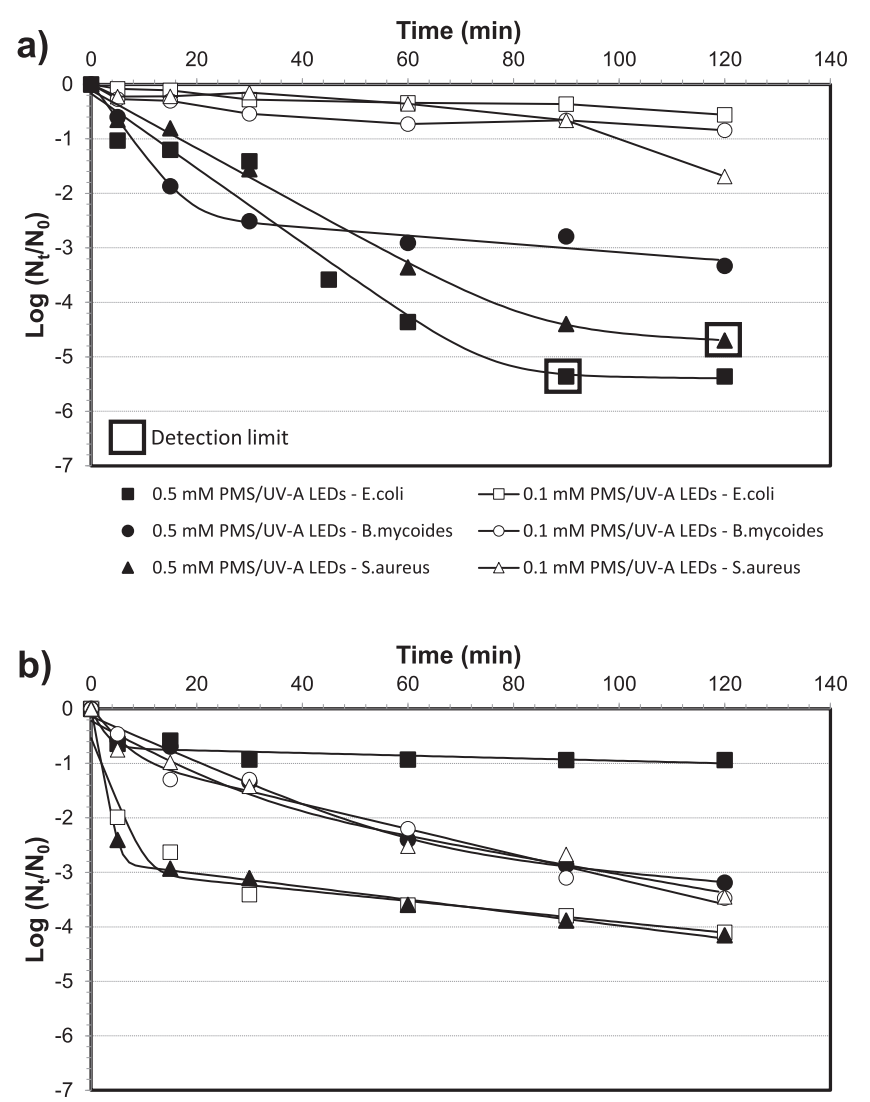

$0.5 \mathrm{mM}$ PMS $/ 0.5 \mathrm{mM}$ Co(II)/UV-A LEDs - E.coli $0.5 \mathrm{mM}$ PMS/0.5 mM Co(II)/UV-A LEDs - B.mycoides $00.5 \mathrm{mM} \mathrm{PMS} / 0.5 \mathrm{mM} \mathrm{Fe}(\mathrm{II}) /$ UV-A LEDs - B.mycoides $\triangle 0.5 \mathrm{mM}$ PMS $/ 0.5 \mathrm{mM}$ Co(II)/UV-A LEDs - S.aureus $\triangle 0.5 \mathrm{mM}$ PMS/0.5 mM Fe(II)/UV-A LEDs - S.aureus

Fig. 4. Inactivation of E. coli, B. mycoides and S. aureus in RWW after the application of: (a) PMS/UV-A LED (Fitted to Biphasic model); (b) PMS/M ${ }^{\mathrm{n}+}$ [Fe(II) or Co(II)]/UV-A LED] (Fitted to Biphasic model). 
results shown in Fig. 1, a dosage of $0.1 \mathrm{mM}$ of PMS was not enough to reach $1-\log$ unit after 120 min of treatment, which was a poor result in comparison with the SWW results. Despite the use of $0.5 \mathrm{mM}$ of PMS leading to the attainment of the DL of E. coli (5.36 $\log$ ) and S. aureus (4.70 $\log$ ), a low inactivation yield, reaching 3.33 $\log$ units, far from the requisite DL of 4.51 , was obtained in the case of $B$. mycoides. Fig. $4 \mathrm{~b}$ shows the bacteria inactivation results after the single addition of $\mathrm{Fe}(\mathrm{II})$ and $\mathrm{Co}(\mathrm{II})$ combined with PMS, where it can be seen that a $0.1 \mathrm{mM}$ concentration of reagents was not sufficient to activate the PMS, reaching similar values to those obtained in the absence of a transition metal. A five-fold increase in $\mathrm{PMS} / \mathrm{M}^{\mathrm{n}+}$ concentration increased the inactivation rate of $E$. coli and $S$. aureus but had no effect on $B$. mycoides, most probably due to its ability to form endospores. In the case of $E$. coli, the inactivation rate was increased but not the final yield $(4.10 \mathrm{log})$ during the treatment without $\mathrm{Fe}(\mathrm{II})$ (5.36 log). For B. mycoides, the combination of PMS/ $\mathrm{Fe}^{2+}$, although decreasing the inactivation rate, did not affect the final inactivation yield, which reached a slightly superior value (3.45 log) than the photolytic activation of PMS $(3.33 \mathrm{log}$ ). The combination PMS/Co(II) (Fig. 4b) negatively affected the result for the inactivation of $E$. coli compared to the PMS/Fe(II) treatment. The effect was totally the opposite for $S$. aureus, which reached a higher inactivation level using $\mathrm{Co}(\mathrm{II})$ as a promoter. For B. mycoides the inactivation yield was almost the same when combining PMS with $\mathrm{Fe}(\mathrm{II})$ or $\mathrm{Co}(\mathrm{II})$. The kinetic parameters obtained through the fitting of inactivation results in the different mathematical models can be observed in Table 5. In general, the inactivation rate of $B$. mycoides was higher than E. coli and S. aureus for PMS/UV-A LEDs treatments, although a higher inactivation yield was attained for $E$. coli owing to spore formation by B. mycoides. However, the kinetic rates observed in Fig. $4 \mathrm{~b}$ confirm that the situation was different when activation of PMS using $\mathrm{Fe}(\mathrm{II})$ or $\mathrm{Co}(\mathrm{II})$ was applied. When $\mathrm{Fe}(\mathrm{II})$ is combined with PMS, the highest inactivation rate belongs to $E$. coli, followed by $S$. aureus and B. mycoides, whereas with $\mathrm{Co}(\mathrm{II}), S$. aureus presents the fastest inactivation rate. For B. mycoides, compared to the PMS/ UV-A LEDs treatments, the combination of PMS with a transition metal slowed down the inactivation rate as a consequence of rapid physiological changes in the cell relating to endospore formation in the first minute of contact time.
With regards to the inactivation of $C$. albicans, the results after the application of the different treatments in a RWW, (Fig. 5 and Table 6), suggest that the application of these operational conditions achieved similar or even a slightly better results than those obtained in SWW. The comparison of inactivation rates obtained by Biphasic model clearly shows that PMS/Co(II)/UV-A LEDs treatment $\left(k_{1}=1.40 \mathrm{~min}^{-1} ; k_{2}=0.02 \mathrm{~min}^{-1}\right)$ was faster than treatments with $\mathrm{Fe}(\mathrm{II})\left(k_{1}=0.45 \mathrm{~min}^{-1} ; k_{2}=0.02 \mathrm{~min}^{-1}\right)$, and as expected, even faster than PMS/UV-A LEDs treatments $\left(k_{1}=0.16 \mathrm{~min}^{-1} ; k_{2}=0.02\right.$ $\left.\mathrm{min}^{-1}\right)$. However, in terms of COD removal (Table 4 ) the yield of the treatments are low, with values ranging from 10 to $20 \%$.

\section{Discussion}

The main objective of this work was to explore alternatives to conventional technologies in wastewater treatment and reuse. Overall, the PMS $/ \mathrm{M}^{\mathrm{n}+} / \mathrm{UV}-\mathrm{A}$ LED treatments showed an extraordinary efficiency in microbial inactivation, thus, they could be used as tertiary treatment in the WWTPs. Thereafter, the treated effluents could be reused in different parts of the wine operational process taking into account their final quality. In Portugal, the reuse of treated urban wastewater is regulated by the guideline NP 4434:2005, in which maximum contaminant levels are established taking into account the intended type of water irrigation reuse: agricultural, forestry, ornamental, garden and other green spaces. With regards to microbiological contamination, the pathogens controlled by this law are faecal coliforms and helminth eggs. Extrapolating the inactivation results of $E$. coli, a faecal coliform, the treated effluents could be reused in the irrigation of vineyards, since the NP 4434:2005 allows reusing treated effluents with a concentration ranging from $10^{2}-10^{4} \mathrm{CFU} / 100 \mathrm{~mL}$. Furthermore, the effluents treated with PMS $/ \mathrm{M}^{\mathrm{n}+} / \mathrm{UV}-\mathrm{A}$ LEDs conform to the legal limits established by WHO and EPA for wastewater reuse (WHO, 2006; USEPA, 2012). Both organizations stipulate the absence of faecal coliforms in treated wastewater for reuse in the irrigation of products for human raw consumption. For remaining products, concentrations in water for irrigation may range from $10^{2}-10^{4} \mathrm{CFU} / 100 \mathrm{~mL}$.

The studied treatment processes, based on the generation of free sulphate radicals through the combination of PMS with UV-A LED

Table 5

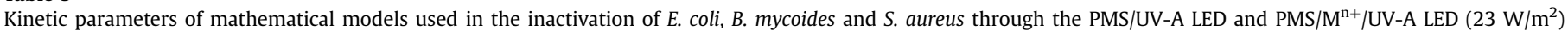
treatments in RWW.

\begin{tabular}{|c|c|c|c|c|c|c|c|c|c|c|}
\hline \multirow[t]{2}{*}{ Disinfection Treatment } & \multirow[t]{2}{*}{ Kinetic model } & \multicolumn{3}{|l|}{ E. coli } & \multicolumn{3}{|l|}{ B. mycoides } & \multicolumn{3}{|l|}{ S. aureus } \\
\hline & & $\begin{array}{l}k_{1}\left(\min ^{-1}\right) / \\
\delta_{1}(\min )\end{array}$ & $\begin{array}{l}k_{2}\left(\min ^{-1}\right) / \\
\delta_{2}(\min )\end{array}$ & $\overline{\mathrm{R}^{2} / \mathrm{RMSD}}$ & $\begin{array}{l}k_{1}\left(\min ^{-1}\right) / \\
\delta_{1}(\min )\end{array}$ & $\begin{array}{l}k_{2}\left(\min ^{-1}\right) / \\
\delta_{2}(\min )\end{array}$ & $\overline{\mathrm{R}^{2} / \mathrm{RMSD}}$ & $\begin{array}{l}k_{1}\left(\min ^{-1}\right) / \\
\delta_{1}(\min )\end{array}$ & $\begin{array}{l}k_{2}\left(\min ^{-1}\right) / \\
\delta_{2}(\min )\end{array}$ & $\overline{\mathrm{R}^{2} / \mathrm{RMSD}}$ \\
\hline \multirow[t]{9}{*}{$0.5 \mathrm{mM}$ PMS/UV-A LED } & $\mathrm{L}(k)$ & - & - & - & - & - & - & 0.09 & - & $0.96 / 0.43$ \\
\hline & $\mathrm{H}(k)$ & 0.26 & - & $0.93 / 0.53$ & 0.66 & - & $0.93 / 0.30$ & 0.15 & - & $0.98 / 0.27$ \\
\hline & $\mathrm{LT}(k)$ & - & - & - & 0.25 & - & $0.97 / 0.27$ & 0.12 & - & $0.99 / 0.18$ \\
\hline & $\operatorname{LST}(k)$ & - & - & - & - & - & - & 0.12 & - & $0.99 / 0.21$ \\
\hline & $\mathrm{W}(\delta)$ & 7.46 & - & $0.93 / 0.67$ & - & - & $0.92 / 0.19$ & 12.58 & - & $0.98 / 0.35$ \\
\hline & $\mathrm{WT}(\delta)$ & 21.41 & - & $0.97 / 0.49$ & - & - & - & 19.85 & - & $0.99 / 0.21$ \\
\hline & $\mathrm{DW}(\delta)$ & - & - & - & 7.99 & 133.58 & $0.99 / 0.16$ & 21.07 & 153.66 & $0.99 / 0.20$ \\
\hline & $\mathrm{B}(k)$ & 0.16 & 0.002 & $0.97 / 0.52$ & 0.31 & 0.02 & $0.99 / 0.16$ & 0.12 & 0.01 & $0.99 / 0.21$ \\
\hline & $\mathrm{BS}(k)$ & - & - & - & 0.33 & 0.02 & $0.99 / 0.19$ & 0.12 & 0.01 & $0.99 / 0.25$ \\
\hline \multirow{5}{*}{$\begin{array}{l}0.5 \mathrm{mM} \text { PMS/0.5 } \\
\text { mM Fe(II)/UV-A LED }\end{array}$} & $\mathrm{L}(k)$ & - & - & - & 0.06 & - & $0.94 / 0.34$ & 0.06 & - & $0.95 / 0.32$ \\
\hline & $\mathrm{H}(k)$ & 1.52 & - & $0.99 / 0.14$ & 0.24 & - & $0.98 / 0.15$ & 0.20 & - & $0.98 / 0.16$ \\
\hline & $\mathrm{LT}(k)$ & 0.38 & - & $0.92 / 0.51$ & 0.08 & - & $0.96 / 0.32$ & - & - & - \\
\hline & $\mathrm{W}(\delta)$ & - & - & - & 14.42 & - & $0.98 / 0.20$ & 15.42 & $0.98 / 0.21$ & \\
\hline & $\mathrm{B}(k)$ & 0.55 & 0.02 & $0.95 / 0.44$ & 0.13 & 0.04 & $0.98 / 0.27$ & 0.33 & 0.05 & $0.99 / 0.21$ \\
\hline $0.5 \mathrm{mM}$ PMS/0.5 mM & $\mathrm{L}(k)$ & - & - & - & 0.06 & - & $0.94 / 0.32$ & - & - & - \\
\hline \multirow[t]{5}{*}{ Co(II)/UV-A LED } & $\mathrm{H}(k)$ & 0.48 & - & $0.94 / 0.08$ & 0.17 & - & $0.98 / 0.15$ & 1.80 & - & $0.99 / 0.06$ \\
\hline & $\mathrm{LT}(k)$ & - & - & - & 0.09 & - & $0.99 / 0.16$ & 1.12 & - & $0.91 / 0.52$ \\
\hline & $\mathrm{W}(\delta)$ & - & - & - & 16.79 & - & $0.98 / 0.19$ & 0.03 & - & $0.99 / 0.08$ \\
\hline & $\mathrm{B}(k)$ & 0.59 & 0.01 & $0.92 / 0.14$ & 0.10 & 0.02 & $0.99 / 0.16$ & 1.20 & 0.03 & $0.99 / 0.07$ \\
\hline & $\mathrm{BS}(k)$ & - & - & - & 0.10 & 0.02 & $0.99 / 0.19$ & - & - & - \\
\hline
\end{tabular}




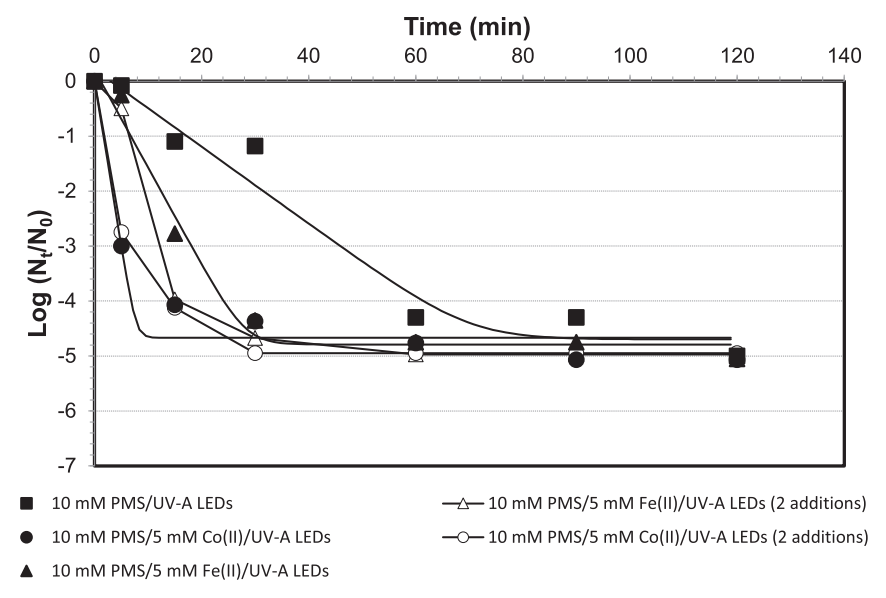

Fig. 5. Inactivation levels of C. albicans in RWW after the PMS/UV-A LED and PMS/M $\mathrm{M}^{\mathrm{n}+}$ [Fe(II) or $\mathrm{Co}(\mathrm{II})] / \mathrm{UV}-\mathrm{A}$ LED] treatments (Fitted to linear with tail model).

radiation, with or without a metal [Fe(II) or Co(II)], successfully achieved the inactivation of different microorganisms (E. coli, B. mycoides, S. aureus and C. albicans). The different means of peroxymonosulphate activation, such as thermal, photolytic or transition metal is well reported elsewhere (Wang and Chu, 2012; Rodríguez-Chueca et al., 2017; Anipsitakis and Dionysiou, 2004b; Antoniou et al., 2010; Ahmed et al., 2014).

The photolysis of PMS, produces one mole of sulphate radical and one mole of hydroxyl radical for each mole of peroxymonosulphate (Equation (2)). Nevertheless, the entire range of UV radiation is not able to activate PMS. The highest PMS photolysis efficiency is reached at $254 \mathrm{~nm}$, whilst, photolysis is usually negligible with visible light $(419 \mathrm{~nm})$ or near-UV radiation $(350 \mathrm{~nm})$ (Wang and Chu, 2012). Thus, if the wavelength is higher than $260 \mathrm{~nm}$, little or no photochemical decomposition of PMS should be observed. In this work, attempts were made to overcome this limitation using a UV-A radiation $(365 \mathrm{~nm})$ from a LED photosystem combined with a transition metal. This manuscript reports the success of photolytic activation of PMS by UV-A LED radiation in the removal of different type of microorganisms. The absence of transition metal as promoter is the main advantage of this treatment. The toxicity of these metals to human health and the environment is well-known, therefore their use should be restricted to very low concentrations. The photolytic activation of PMS was successfully achieved with the UV-A LED/ $\mathrm{M}^{\mathrm{n}+}$ system, which achieved a high level of microorganism inactivation. In a previous study of the degradation of the organic matter present in a winery wastewater (Rodríguez-Chueca et al., 2017), it was shown that Fe(II) and $\mathrm{Co}(\mathrm{II})$ are the best metal to promote a sulphate radical cascade mechanism. For this reason, these metals were chosen to be assessed in the inactivation of the four selected microorganisms. Current literature abounds with research into the optimal metal for PMS activation. Brandt and Van Eldik (1995) reported that the catalystmediated decomposition of PMS could proceed with the formation of sulphate or hydroxyl radicals, depending on what kind of transition metal was used. Some authors have reported $\mathrm{Co}$ (II) as one of the most effective (Sun et al., 2009; Fernández et al., 2004). The reduction of $\mathrm{Co}$ (III) to $\mathrm{Co}$ (II) mediated by the oxidation of PMS is thermodynamically feasible $(0.82 \mathrm{~V})$ and fast, and the process proceeds cyclically many times until PMS is totally consumed (Anipsitakis and Dionysiou, 2003). In the case of using Co(II) as activator of PMS, sulphates radicals dominate, but hydroxyl radicals are generated as well, as can be seen in the mechanism (Eqs. (3)-(8)) (Antoniou et al., 2010):

$\mathrm{Co}^{2+}+\mathrm{HOOSO}_{3}^{-} \rightarrow \mathrm{Co}^{3+}+\mathrm{SO}_{4}^{-}+\mathrm{HO}^{-}$

$\mathrm{Co}^{3+}+\mathrm{HOOSO}_{3}^{-} \rightarrow \mathrm{Co}^{2+}+\cdot \mathrm{OOSO}_{3}{ }^{-}+\mathrm{HO}^{+}$

$\mathrm{HOOSO}_{3}{ }^{-}+\mathrm{e}^{-} \rightarrow \mathrm{SO}_{4}{ }^{-}+\mathrm{HO}^{-}$

$\mathrm{HOOSO}_{3}{ }^{-}+\mathrm{e}^{-} \rightarrow \mathrm{SO}_{4}{ }^{2-} \cdot+\mathrm{HO}^{\bullet}$

$\mathrm{HO}^{\cdot}+\mathrm{SO}_{4}{ }^{2-}\left(\mathrm{HSO}_{4}^{-}\right) \rightarrow \mathrm{SO}_{4}{ }^{-}\left(\mathrm{HSO}_{4}{ }^{-}\right)+\mathrm{HO}^{-}$

$$
\begin{aligned}
& 2 \mathrm{HSO}_{5}{ }^{\cdot} \leftrightarrow \mathrm{HO}_{3} \mathrm{SOOOOSO}_{3} \mathrm{H} \rightarrow\left\{\mathrm{SO}_{4}{ }^{\cdot}\right. \\
& \left.-\mathrm{OOSO}_{4}{ }^{-}\right\}+2 \mathrm{H}^{+} \rightarrow 2 \mathrm{SO}_{4}{ }^{-}+\mathrm{O}_{2}+2 \mathrm{H}^{+}
\end{aligned}
$$

The main disadvantage of using $\mathrm{Co}(\mathrm{II})$ as a promoter is its potential toxicity to the environment. In our experiments, the microorganism inactivation efficiency of PMS/ $/ \mathrm{M}^{\mathrm{n}+} / \mathrm{UV}-\mathrm{A}$ LED was similar using $\mathrm{Fe}(\mathrm{II})$ or $\mathrm{Co}(\mathrm{II})$. Therefore, since $\mathrm{Fe}(\mathrm{II})$ possesses a lower environmental toxicity, it was selected as a promoter. The use of $\mathrm{Fe}(\mathrm{II})$ as PMS activator predominantly promotes the production of sulphate, generating hydroxyl radicals as well. The cycle Fe(III)/ $\mathrm{Fe}(\mathrm{II})$ is accelerated by the photo-reduction of $\mathrm{Fe}(\mathrm{III})$-complexes (equation (9)).

$\mathrm{Fe}(\mathrm{OH})^{2+}+\mathrm{hv} \rightarrow \mathrm{Fe}^{2+}+\mathrm{HO} \cdot$

Sulphate radicals have been demonstrated to be very efficient at microbial inactivation although the mechanism of attack is not yet clear. One of the more feasible hypotheses is based on microbial death as the consequence of over-stress caused by different external agents such as UV radiation, peroxymonosulphate and higher metal concentrations than normal [Fe(II) and $\mathrm{Co}(\mathrm{II})]$. Spuhler et al. (2010) reported in detail the attack mechanism of hydroxyl

Table 6

\begin{tabular}{|c|c|c|c|c|c|c|c|c|c|}
\hline \multirow[t]{2}{*}{ Kinetic model } & \multicolumn{3}{|c|}{$10 \mathrm{mM}$ PMS/UV-A LED } & \multicolumn{3}{|c|}{$10 \mathrm{mM} P M S / 5 \mathrm{mM} \mathrm{Fe}(\mathrm{II}) / \mathrm{UV}-A$ LED } & \multicolumn{3}{|c|}{$10 \mathrm{mM}$ PMS/5 mM Co(II)/UV-A LED } \\
\hline & $\begin{array}{l}k_{1}\left(\min ^{-1}\right) / \\
\delta_{1}(\min )\end{array}$ & $\begin{array}{l}k_{2}\left(\min ^{-1}\right) / \\
\delta_{2}(\min )\end{array}$ & $\overline{\mathrm{R}^{2} / \mathrm{RMSD}}$ & $\overline{k_{1}\left(\min ^{-1}\right) / \delta_{1}(\min )}$ & $k_{2}\left(\min ^{-1}\right) / \delta_{2}(\min )$ & $\overline{\mathrm{R}^{2} / \mathrm{RMSD}}$ & $\begin{array}{l}k_{1}\left(\min ^{-1}\right) / \\
\delta_{1}(\min )\end{array}$ & $\begin{array}{l}k_{2}\left(\min ^{-1}\right) / \\
\delta_{2}(\min )\end{array}$ & $\mathrm{R}^{2} / \mathrm{RMSD}$ \\
\hline $\mathrm{L}(k)$ & 0.10 & - & $0.91 / 0.73$ & - & - & - & - & - & - \\
\hline $\mathrm{H}(k)$ & 0.14 & - & $0.93 / 0.54$ & 0.89 & - & $0.87 / 0.73$ & 2.56 & - & $0.99 / 0.15$ \\
\hline $\operatorname{LT}(k)$ & 0.16 & - & $0.96 / 0.50$ & 0.41 & - & $0.98 / 0.34$ & 1.39 & - & $0.96 / 0.44$ \\
\hline LST $(k)$ & 0.19 & - & $0.97 / 0.53$ & 0.65 & - & $0.99 / 0.29$ & - & - & - \\
\hline $\mathrm{W}(\delta)$ & - & - & - & - & - & - & - & - & - \\
\hline $\mathrm{WT}(\delta)$ & 24.98 & - & $0.98 / 0.47$ & 9.38 & - & $0.99 / 0.29$ & - & - & - \\
\hline $\mathrm{DW}(\delta)$ & 26.13 & 125.73 & $0.98 / 0.42$ & 9.04 & 150.04 & $0.99 / 0.12$ & - & - & - \\
\hline $\mathrm{B}(k)$ & 0.16 & 0.02 & $0.97 / 0.56$ & 0.45 & 0.02 & $0.99 / 0.32$ & 1.40 & 0.02 & $0.99 / 0.16$ \\
\hline $\mathrm{BS}(k)$ & 0.20 & 0.02 & $0.97 / 0.62$ & 0.66 & 0.02 & $0.99 / 0.12$ & - & - & - \\
\hline
\end{tabular}

Kinetic parameters of mathematical models used in the inactivation of $C$. albicans through the PMS/UV-A LED and PMS/M ${ }^{\mathrm{n}+} / \mathrm{UV}-\mathrm{A}$ LED (23 W/m²) treatments in RWW. 
radicals generated in photo-Fenton reaction on Escherichia coli cells. Although all of the mechanism cannot be extrapolated to the sulphate radical attack mechanism, some parts can be considered as common - such as the effect of UV radiation and iron concentration. For instance, UV-A radiation is responsible for harming some crucial metabolic enzymes and other exogenous macromolecules, such as photosensitizers or proteins. The damage and dysfunction of catalase (CAT) and superoxide dismutase (SOD) increases the intracellular concentration of Reactive Oxygen Species (ROS), generating an extra stress condition inside the cell. Apart from oxidative stress caused by UV radiation, the presence of transitions metals such as $\mathrm{Fe}(\mathrm{II})$ and $\mathrm{Co}(\mathrm{II})$ in higher concentrations than normal, can also provoke significant damage (Blaha et al., 2011). The outer membrane cell is composed of different kind of embedded proteins, such as porins or trimeric proteins, with the objective of regulating the selective transport of molecules and metal ions into the cytosol. There is a high-affinity active transport system with the aim of transporting and releasing metal ions into the cytosol in both membranes (outer and inner) and in the plasma (Ma et al., 2009). An excess of metal concentration could provoke cell death. For this reason bacteria usually have detoxification mechanisms such as RcnA and Cation Diffusion Facilitators (CFD), which are the responsible for $\mathrm{Ni}$, Co and Fe removal in E. coli to remove the excess of these metals, (Kolaj-Robin et al., 2015). It follows that an inefficient operation of this detoxification mechanism could cause cell death and Spuhler et al. (2010), reported the hypothesis that E. coli can be damaged by intracellular Fenton reaction as the consequence of extracellular diffusion of $\mathrm{Fe}(\mathrm{II})$ into the cytoplasm and its later reaction with intracellular $\mathrm{H}_{2} \mathrm{O}_{2}$ (via HaberWeiss reaction), which generates hydroxyl radicals that directly attack cellular DNA.

There are few studies regarding the microbial inactivation by sulphate radicals. Nevertheless, their main hypothesis is that the mechanism of attack is based on the premise that the behaviour is similar to hydroxyl radicals attack. Free radicals react with cellular constituents, cause lipid peroxidation in intracellular and cellular membranes, and enhance permeability and inactivation (Spuhler et al., 2010; Reed, 2004; Cabiscol et al., 2000). It is also, wellknown that hydroxyl radicals are the only ROS which can directly damage DNA (Sattler et al., 2000), whereas there are no reports of sulphate radicals' ability to attack DNA.

Although the majority of the literature reported oxidative stress on $E$. coli (Gram-negative bacteria), the mechanism could be quite similar for different bacteria, even Gram-positive bacteria. Consequently, oxidative stress could influence them in a similar way. The main difference should lie in important structural differences, Gram-positive bacteria being in general much more resistant than Gram-negative bacteria (Madigan et al., 2012). Comparing the PMS/ $\mathrm{M}^{\mathrm{n}+} / \mathrm{UV}-\mathrm{A}$ LED effect on Gram-negative and Gram-positive bacteria, E. coli (Gram-negative) seems extremely sensitive to chemical treatments, reaching inactivation values between 3 and $4.5 \mathrm{log}$ in the first minute of treatment. On the other hand, in the case of S. aureus (Gram-positive), the inactivation results were lower than those obtained for E. coli. For the other Gram-positive bacteria, $B$. mycoides, the same treatments were not sufficient to inactivate them. This species can withstand more severe environmental constraints due to its ability to form endospores. These results provide evidence that Gram-positive are more resistant than Gramnegative bacteria under the oxidation conditions applied, the main reasons for the distinctive sensitivities to the applied treatments being structural, chemical and physiological differences. However, both types of bacteria should also present similar efflux pumps which aim to maintain homeostasis in the cytoplasm. Finally, sulphate and hydroxyl radicals directly attack both the cell membranes and DNA, are lethal for bacteria and deter their re-growth. A number of papers also show that $E$. coli is less resistant than Enterococcus faecalis (Gram-positive) to $\mathrm{TiO}_{2}$ and singlet oxygen photocatalytic treatments (Demidova and Hamblin, 2005; Fu et al., 2005; Page et al., 2007). They attribute this resistance to: (i) the presence of the outer membrane, which adds an extra wall of protection against oxidative agents (Fu et al., 2005; Villén et al., 2006; Page et al., 2007); (ii) the absence of an outer membrane in Gram-positive bacteria, which makes it easier for hydroxyl radicals to damage the bacterial DNA; and (iii) differences in the chemical composition of the cell wall and protection mechanisms between Gram-positive and Gram-negative bacteria (Demidova and Hamblin, 2005).

Examples of water disinfection are abundant in the literature on SR-AOPs. Anipsitakis et al. reported the use of PMS in combination with traces of $\mathrm{Co}(\mathrm{II})$ as an in situ swimming-pool sanitizer (Anipsitakis et al., 2008). The application of $25 \mathrm{mg} / \mathrm{L}$ of PMS and $0.1 \mathrm{mg} / \mathrm{L}$ of $\mathrm{Co}(\mathrm{II})$ proved to be efficient in bacterial removal, but rather slow as a sanitizer. Under these conditions in pool water, a 4$\log$ kill of E. coli was achieved after 60 min of treatment. However, this result was not effective enough to qualify as an EPA-registered sanitizer for swimming pools, since this requires 6-log kill of $E$. coli, ATCC 11229, and Enterococcus faecium ATCC 6569, in 30 s. The results presented in the present study show that an application of 0.1 / $0.1 \mathrm{mM}$ PMS/Co(II)/UV-A LED radiation reached almost 3 log kill of E. coli after $1 \mathrm{~min}$ of exposure. Although this value is insufficient for use in swimming-pool sanitisation, it nevertheless remains an improvement on the value reported by Anipsitakis et al. (2008).

Our work also illustrates the high resilience of $C$. albicans to the tested treatments. Kühn et al. reported the higher resistance of C. albicans versus other microorganisms such as E. coli, Pseudomonas aeruginosa, S. aureus and E. faecium under $\mathrm{TiO}_{2} / \mathrm{UV}$ treatments (Kühn et al., 2003). C. albicans is a commensal and common organism of the gut and mucosa microbiome. Despite this, in some circumstances it is capable of turning into a functional pathogen, since it has the ability to withstand the high oxidative stress caused by the first line of defense, the macrophages. To survive the oxidative burst provoked by macrophages, $C$. albicans encodes a panoply of anti-oxidant, extra or intra-cellular, enzymes such a catalase (cat1), six superoxide dismutases, and three flavohemoglobins enzymes (Jiménez-López and Lorenz, 2013). As a consequence, $C$. albicans is naturally resistant to oxidative radicals such as sulphate radicals (SOS).

Along with the oxidative stress caused by PMS, the transition metal can also be also toxic to microorganisms. In yeasts, metals as Fe and $\mathrm{Co}$ are involved in ROS generation, in competition with other metals such zinc, for the binding to macromolecules, possibly resulting in the inhibition of their proper function, increase lipid peroxidation and oxidative DNA damage, damaging both cellular membrane and DNA), and involved in depletion of glutathione (GSH), a major antioxidant in eukaryotic cells (Conklin et al., 1992; Simonsen et al., 2012). Also, cobalt chemical affinity for sulfur atoms may be a possible mechanism of cobalt toxicity, since inhibit proteins whose activity depends on thiol groups (Barceloux, 1999).

It may seem a paradox that the highest dosage of PMS studied presents a scavenger effect for COD removal, whilst it is the correct dosage for achieving total inactivation of $C$. albicans. Nevertheless, it is crucial to consider the complexity of the organic load in the samples, taking into account the possible transformation of some organic compounds without decreasing the COD value. In addition, the existence of competition between microorganisms and organic matter for free radicals is highly probable. Some authors have reported that the presence of Dissolved Organic Matter (DOM) affects photocatalytic efficiency. Natural organic matter has a positive effect on the photo-Fenton process at near-neutral $\mathrm{pH}$ when it is used for microbial inactivation (Moncayo-Lasso et al., 2009; Murray and 
Parsons, 2004; Georgi et al., 2007). Wastewater usually has a high load of DOM which can have a variable composition dependent on origin. Thus, DOM is a highly complex mixture of organic compounds generated by the decomposition and bio-processing of macro-cellular structures. Because of this variability of wastewater composition, the effect of treatment on DOM could vary, depending on the types of organic compounds generated and present in different waters. It is well known that some organic acids, such as oxalic, carboxylic, humic and fulvic acids and other intermediates, have a significant effect on the photodegradation of a variety of pharmaceuticals through a number of processes (Xu et al., 2011). Nevertheless, the presence of DOM has also been observed to decrease the rate of photodegradation by acting as a sunlight filter (Tixier et al., 2002).

\section{Conclusions}

PMS/UV-A LED and PMS/M $\mathrm{M}^{\mathrm{n}+} / \mathrm{UV}-\mathrm{A}$ LED are a viable alternative as tertiary treatment for water reuse in WWTPs, allowing reuse the effluents in the irrigation of the vineyard, for example. When a low dosage of PMS (0.1 mM) was activated through UV-A LED radiation at $\mathrm{pH} 5$, total inactivation of $E$. coli, and extensive inactivation levels for $B$. mycoides $(\approx 3 \log$ ) and S. aureus $(\approx 4 \log$ ) were achieved after 90 min of contact time. However, higher dosages of PMS (10 mM) are necessary to totally inactivate $C$. albicans due to its higher resilience to oxidative stress. The inactivation rate was accelerated by the metal activation of PMS through the use of a transition metal [Fe(II) or $\mathrm{Co}(\mathrm{II})]$. This acceleration was mainly observed in the first minute of contact time, reaching inactivation values ranging from 1 to $3 \mathrm{log}$. In general terms, small differences were observed between the use of $\mathrm{Fe}(\mathrm{II})$ or $\mathrm{Co}(\mathrm{II})$ as promoter, however in the case of $S$. aureus and C. albicans the combination of PMS with Co(II) obtained higher inactivation values than $\mathrm{Fe}(\mathrm{II})$, because of its higher toxicity to eukaryotic cells.

In contrast to the above, important differences were observed among the inactivation patterns of $E$. coli (Gram-negative), $B$. mycoides and S. aureus (Gram-positive). The oxidative stress generated by the complexity of PMS/ $\mathrm{M}^{\mathrm{n}+} / \mathrm{UV}-\mathrm{A}$ LED treatments most probably triggered endospore formation in B. mycoides and more demanding operational conditions were required to reach the total inactivation of this sporulated bacterial species. Consequently, Gram-positive bacteria could be considered a more reliable indicator in control of the quality of disinfection than the commonly used E. coli.

The Hom model satisfactorily fitted the inactivation results of all studied microorganisms in all applied treatments. Furthermore, mathematical models based on Weibull distributions and biphasic and biphasic with shoulder models accurately described the inactivation curve of microorganisms in some of the studied treatments. These models are based on the hypothesis that the bacteria populations have sub-groups with different resilience to the treatments proposed, which is a very plausible scenario in the WWTPs microbiome, where microorganisms from different environments and substrates are frequently mixed.

\section{Acknowledgments}

The authors are grateful to European Investment Funds by FEDER/COMPETE/POCI (POCI-01-0145-FEDER-006958) and National Funds by FCT under the projects UID/AGR/04033/2013 and UID/QUI/00616/2013. Project INNOFOOD - INNOvation in the FOOD sector through the valorization of food and agro-food byproducts - NORTE-07-0124-FEDER-0000029, Project INTERACT Integrative Research in Environment, Agro-Chains and Technology - NORTE-01-0145-FEDER-000017 and Project INNOVINE \& WINE -
Innovation Platform of Vine and Wine - NORTE-01-0145-FEDER000038. Jorge Rodríguez-Chueca also acknowledges the funding provided by the Spanish Ministry of Economy and Competitiveness (MINECO) through the Juan de la Cierva-formación grant (No FJCI2014-20195). Marco S. Lucas also acknowledges the funding provided by the European Union's Horizon 2020 research and innovation programme under the Marie Sklodowska-Curie grant agreement No 660969.

\section{Appendix A. Supplementary data}

Supplementary data related to this article can be found at http:/ dx.doi.org/10.1016/j.jclepro.2017.02.135.

\section{References}

Ahmed, M.M., Brienza, M., Goetz, V., Chiron, S., 2014. Solar photo-Fenton using peroxymonosulfate for organic micropollutants removal from domestic wastewater: comparison with heterogeneous $\mathrm{TiO}_{2}$ photocatalysis. Chemosphere 117, 256-261.

Anipsitakis, G.P., Dionysiou, D.D., 2003. Degradation of organic contaminants in water with sulfate radicals generated by the conjunction of peroxymonosulfate with cobalt. Environ. Sci. Technol. 37, 4790-4797.

Anipsitakis, G.P., Dionysiou, D.D., 2004a. Radical generation by the interaction of transition metals with common oxidants. Environ. Sci. Technol. 38, 3705-3712.

Anipsitakis, G.P., Dionysiou, D.D., 2004b. Transition metal/UV-based advanced oxidation technologies forwater decontamination. Appl. Catal. B Environ. 54 $155-163$.

Anipsitakis, G.P., Tufano, T.P., Dionysiou, D.D., 2008. Chemical and microbial decontamination of pool water using activated potassium peroxymonosulfate. Water Res. 42 (12), 2899-2910.

Antoniou, M.G., de la Cruz, A.A., Dionysiou, D.D., 2010. Degradation of microcystinLR using sulfate radicals generated through photolysis, thermolysis and etransfer mechanisms. Appl. Catal. B Environ. 96 (3-4), 290-298.

Awad, M.F., Kraume, M., 2011. Keratinophilic fungi in activated sludge of wastewater treatment plants with MBR in Berlin, Germany. Mycology 2, 276-282.

Bandala, E.R., Peláez, M.A., Dionysiou, D.D., Gelover, S., Garcia, J., Macías, D., 2007 Degradation of 2,4-dichlorophenoxyacetic acid (2,4-D) using cobaltperoximonosulfate in Fenton-like process. Photochem. Photobiol. A 186 357-363.

Barceloux, D.G., 1999. Cobalt. J. Toxicol. Clin. Toxicol. 37 (2), 201-206.

Blaha, D., Arous, S., Blériot, C., Dorel, C., Mandrand-Berthelot, M., Rodrigue, A., 2011. The Escherichia coli metallo-regulator RcnR represses rcnA and rcnR transcription through binding on a shared operator site: insights into regulatory specificity towards nickel and cobalt. Biochimie 93 (3), 434-439.

Börjesson, S., Matussek, A., Melin, S., Löfgren, S., Lindgren, P.E., 2010. Methicillinresistant Staphylococcus aureus (MRSA) in municipal wastewater: an uncharted threat? J. Appl. Microbiol. 108, 1244-1251.

Bottone, E.J., 2010. Bacillus cereus, a volatile human pathogen. Clin. Microbiol. Rev. 23, 382-398.

Brandt, C., Van Eldik, R., 1995. Transition metal-catalyzed oxidation of sulfur (IV) oxides. Atmospheric-relevant processes and mechanisms. Chem. Rev. 95 (1), $119-190$.

Cabiscol, E., Tamarit, J., Ros, J., 2000. Oxidative stress in bacteria and protein damage by reactive oxygen species. Int. Microbiol. 3 (1), 3-8.

Calderone, R.A., 2002. Candida and Candidiasis. ASM Press, Washington DC, USA.

Conklin, D.S., McMaster, J.A., Culbertson, M.R., Kung, C., 1992. COT1, a gene involved in cobalt accumulation in Saccharomyces cerevisiae. Mol. Cell. Biol. 12, 3678-3688.

Cristóvão, R.O., Botelho, C.M., Martins, R.J.E., Loureiro, J.M., Boaventura, R.A.R., 2015 Fish canning industry wastewater treatment for water reuse - a case study. J. Clean. Prod. 87, 603-612.

Demidova, T.N., Hamblin, R., 2005. Effect of cell-photosensitizer binding and cell density on microbial photoinactivation. Antimicrob. Agents Chemother. 49, 2329-2335.

Douglas, L.J., 1988. Candida proteinases and candidosis. Crit. Rev. Biotechnol. 8, $121-129$.

Drobniewski, F.A., 1993. Bacillus cereus and related species. Clin. Microbiol. Rev. 6, 324-338.

Eaton, A.D., Clesceri, L.S., Rice, E.W., Greenberg, A.E., Franson, M.A.H., 2005. Standard Methods for the Examination of Water and Wastewater, twenty-first ed. APA-AWWA-WEF, Washington, DC (USA).

European Directive 91/271/EEC, Official Bulletin of Europe Union L135, 30th May 1991 Brussels (Belgium).

Fernández, J., Maruthamuthu, P., Renken, A., Kiwi, J., 2004. Bleaching and photobleaching of Orange II within seconds by the oxone $/ \mathrm{Co}^{2+}$ reagent in Fenton-like processes. Appl. Catal. B Environ. 49 (3), 207-215.

Ferreira, L.C., Lucas, M.S., Fernandes, J.R., Tavares, P.B., 2016. Photocatalytic oxidation of reactive Black 5 with UV-A LEDs. J. Environ. Chem. Eng. 4 (1), 109-114.

$\mathrm{Fu}, \mathrm{G}$., Vary, P.S., Lin, C.T., 2005. Anatase $\mathrm{TiO}_{2}$ nanocomposites for antimicrobial 
coatings. J. Phys. Chem. B 109, 8889-8898.

Geeraerd, A.H., Valdramidis, V.P., Van Impe, J.F., 2005. GInaFiT, a freeware tool to assess non-log-linear microbial survivor curves. Int. J. Food Microbiol. 102, 95-105.

Georgi, A., Schierz, A., Trommler, U., Horwitz, C., Collins, T., Kopinke, F.D., 2007. Humic acid modified Fenton reagent for enhancement of the working $\mathrm{pH}$ range. Appl. Catal. B Environ. 72 (1-2), 26-36.

Goldstein, R.E., Micallef, S.A., Gibbs, S.G., Davis, J.A., He, X., George, A. Kleinfelter, L.M., Schreiber, N.A., Mukherjee, S., Sapkota, A., Joseph, S.W. Sapkota, A.R., 2012. Methicillin-resistant Staphylococcus aureus (MRSA) detected at four U.S. wastewater treatment plants. Environ. Health Perspect. 120, $1551-1558$.

Jiménez-López, C., Lorenz, M.C., 2013. Fungal immune evasion in a mode host-pathogen interaction: Candida albicans versus macrophages. PLoS Pathog. 9 (11), 1-4.

Jourjon, F., Khaldi, S., Reveillere, M., Thibault, C., Poulard, A., Chretien, P., Bednar, J., 2005. Microbiological characterization of winery effluents: an inventory of the sites for different treatment systems. Water Sci. Technol. 51 (1), 19-26.

Kolaj-Robin, O., Russell, D., Hayes, K.A., Pembroke, J.T., Soulimane, T., 2015. Cation diffusion facilitator family: structure and function. FEBS Lett. 589 (12) 1283-1295.

Kühn, K.P., Chaberny, I.F., Massholder, K., Stickler, M., Benz, V.W., Sonntag, Erdinger L., 2003. Disinfection of surfaces by photocatalytic oxidation with titanium dioxide and UVA light. Chemosphere 53 (1), 71-77.

Leclerc, H., Mossel, D.A.A., Edberg, S.C., Struijk, C.B., 2001. Advances in the bacteriology of the coliform group: their suitability as markers of microbial water safety. Annu. Rev. Microbiol. 55, 201-234.

Lucas, M.S., Peres, J.A., Li Puma, G., 2010. Treatment of winery wastewater by ozonebased advanced oxidation processes $\left(\mathrm{O}_{3}, \mathrm{O}_{3} / \mathrm{UV}\right.$ and $\left.\mathrm{O}_{3} / \mathrm{UV} / \mathrm{H}_{2} \mathrm{O}_{2}\right)$ in a pilotscale bubble column reactor and process economics. Sep. Purif. Technol. 72 (3), 235-241.

Ma, Z., Jacobsen, F.E., Giedroc, D.P., 2009. Coordination chemistry of bacterial meta transport and sensing. Chem. Rev. 109, 4644-4681.

Madigan, M.T., Martinki, J.M., Dunlap, P.V., Clark, D.P., 2012. Brock: Biology of Microorganisms, thirteenth ed. Pearson Education, San Francisco (United States of America).

Malandra, L., Wolfaardt, G., Zietsman, A., Viljoen-Bloom, M., 2003. Microbiology of a biological contactor for winery wastewater treatment. Water Res. 37 (17), 4125-4134.

Moncayo-Lasso, A., Sanabria, J., Pulgarin, C., Benítez, N., 2009. Simultaneous E. coli inactivation and NOM degradation in river water via photo-Fenton process at natural pH in solar CPC reactor. A new way for enhancing solar disinfection of natural water. Chemosphere 77 (2), 296-300.

Murray, C.A., Parsons, S.A., 2004. Removal of NOM from drinking water: Fenton's and photo-Fenton's processes. Chemosphere 54 (7), 1017-1023.

Nataro, J.P., Kaper, J.B., 1998. Diarrheagenic Escherichia coli. Clin. Microbiol. Rev. 11, $142-201$.

NP 4434:2005, 2005. Norma Portuguesa sobre reutilização de águas residuais urbanas tratadas na rega. Instituto Português da Qualidade, Caparica (Portugal).

Page, K., Palgrave, R.G., Parkin, I.P., Wilson, M., Savin, S.L.P., Chadwick, A.V., 2007 Titania and silver-titania composite films on glass - potent antimicrobial coatings. J. Mater. Chem. 17, 95-104.

Reed, R.H., 2004. The inactivation of microbes by sunlight: solar disinfection as a water treatment process. Adv. Appl. Microbiol. 54, 333-365.

Rodrigues, C.S.D., Neto, A.R., Duda, R.M., de Oliveira, R.A., Boaventura, R.A.R., Madeira, L.M., 2017. Combination of chemical coagulation, photo-Fenton oxidation and biodegradation for the treatment of vinasse from sugar cane ethanol distillery. J. Clean. Prod. 142 (4), 3634-3644.

Rodríguez-Chueca, J., Mosteo, R., Ormad, M.P., Ovelleiro, J.L., 2012. Factorial experimental design applied to Escherichia coli disinfection by Fenton and photo-
Fenton processes. Sol. Energy 86 (11), 3260-3267.

Rodríguez-Chueca, J. Ferreira, LC. Fernandes, J.R. Tavares, P.B. Lucas, M.S., Peres, J.A., 2015. Photocatalytic discolouration of Reactive Black 5 by UV-A LEDs and solar radiation. J. Environ. Chem. Eng. 3 (4), 2948-2956.

Rodríguez-Chueca, J., Amor, C., Fernandes, J.R., Tavares, P.B., Lucas, M.S., Peres, J.A., 2016. Treatment of crystallized-fruit wastewater by UV-A LED photo-Fenton and coagulation-flocculation. Chemosphere 145, 351-359.

Rodríguez-Chueca, J., Amor, C., Silva, T., Dionysiou, D.D., Li Puma, G., Lucas, M.S., Peres, J.A., 2017. Treatment of winery wastewater by sulphate radicals: $\mathrm{HSO}_{5}^{-}$ transition metal/UV-A LEDs. Chem. Eng. J. 310 (2), 473-483.

Santos, C., Lucas, M.S., Dias, A.A., Bezerra, R.M.F., Peres, J.A., Sampaio, A., 2014. Winery wastewater treatment by combination of Cryptococcus laurentii and Fenton's reagent. Chemosphere 117, 53-58.

Sattler, U., Calsou, P., Boiteux, S., Salles, B., 2000. Detection of oxidative base DNA damage by a new biochemical assay. Arch. Biochem. Biophys. 376 (1), 26-33.

Schaeffer, A.B., Fulton, M., 1933. A simplified method of staining endospores. Science 77, 194.

Simonsen, L.O., Harbak, H., Bennekou, P., 2012. Cobalt metabolism and toxicology a brief update. Sci. Total Environ. 432, 210-215.

Singleton, V.L., Rossi, J.A., 1965. Colorimetry of total phenolics with phosphomolybdic-phosphotungstic acid reagents. Am. J. Enol. Vitic. 16, 144-158.

Spuhler, D., Rengifo-Herrera, J.A., Pulgarin, C., 2010. The effect of $\mathrm{Fe}^{2+}, \mathrm{Fe}^{3+}, \mathrm{H}_{2} \mathrm{O}_{2}$ and the photo-Fenton reagent at near neutral $\mathrm{pH}$ on the solar disinfection (SODIS) at low temperatures of water containing Escherichia coli K12. Appl. Catal. B 96 (1-2), 126-141.

Sun, J., Li, X., Feng, J., Tian, X., 2009. Oxone $/ \mathrm{Co}^{2+}$ oxidation as an advanced oxidation process: comparison with traditional Fenton oxidation for treatment of landfill leachate. Water Res. 43 (17), 4363-4369.

Tixier, C., Singer, H.P., Canonica, S., Müller, S.R., 2002. Phototransformation of triclosan in surface Waters: a relevant elimination process for this widely used biocide-laboratory studies, field measurements, and modeling. Environ. Sci. Technol. 36, 3482-3489.

Thompson, J.M., Gündoğdu, A., Stratton, H.M., Katouli, M., 2012. Antibiotic resistant Staphylococcus aureus in hospital wastewaters and sewage treatment plants with special reference to methicillin-resistant Staphylococcus aureus (MRSA). J. Appl. Microbiol. 114, 44-54.

USEPA, 1993. Method 410.4. The Determination of Chemical Oxygen Demand by Semi-automated Colorimetry. United States Environmental Protection Agency, Washington DC (USA).

USEPA, 2012. Guidelines for Water Reuse. United States Environmental Protection Agency, Washington DC (USA).

Villén, L., Manjón, F., García-Fresnadillo, D., Orellana, G., 2006. Solar water disinfection by photocatalytic singlet oxygen production in heterogeneous medium. Appl. Catal. B Environ. 69, 1-9.

Wang, Y.R., Chu, W., 2012. Photo-assisted degradation of 2,4,5-trichlorophenoxyacetic acid by $\mathrm{Fe}(\mathrm{II})$-catalyzed activation of Oxone process: the role of UV irradiation, reaction mechanism and mineralization. Appl. Catal. B Environ. $123-124,151-161$

Wei, G., Liang, X., He, Z., Liao, Y., Xie, Z., Liu, P., Ji, S., He, H., Li, D., Zhang, J., 2015. Heterogeneous activation of Oxone by substituted magnetites $\mathrm{Fe}_{3}-\mathrm{xM}_{\mathrm{X}} \mathrm{O}_{4}(\mathrm{Cr}$ $\mathrm{Mn}, \mathrm{Co}, \mathrm{Ni}$ ) for degradation of Acid Orange II at neutral pH. J. Mol. Catal. A Chem. 398, 86-94.

WHO, 2006. Guidelines for the Safe Use of Wastewater, Excreta and Greywater: World Health Organization, Geneve (Switzerland).

Xu, H., Cooper, W.J., Jung, J., Song, W., 2011. Photosensitized degradation of amoxicillin in natural organic matter isolate solutions. Water Res. 45, 632-638.

Yu, Z.Y., Kiwi-Minsker, L., Renken, A., Kiwi, J., 2006. Detoxification of diluted azodyes at biocompatible $\mathrm{pH}$ with the Oxone $/ \mathrm{Co}^{2+}$ reagent in dark and light processes. J. Mol. Catal. A Chem. 252, 113-119. 